İstanbul Ticaret Üniversitesi Sosyal Bilimler Dergisi Yll:19 Sayl:39 Güz:2020/3 s.1453-1484 DOI: https://doi.org/10.46928/iticusbe.759056

\title{
Teorik Makale
}

\section{KÜRESEL ISINMA VE İKLIM DEĞIŞ̧iKLİĞİ: BİLIMSEL UZLAŞMADAN POLITIKK AYRIŞMAYA}

\author{
Seyhun DOĞAN ${ }^{1}$ ORCID ID: 0000-0003-3450-0612 \\ Ebru DOĞAN ${ }^{2}$ ORCID ID: 0000-0003-0832-9030 \\ Mutlu TÜZER ${ }^{3}$ ORCID ID: 0000-0001-9125-2542
}

\section{ÖZET}

İklim bilimi literatüründe, önde gelen iklim bilimciler arasında iklim değişikliği üzerindeki bilimsel uzlaşmayı gözlemlemek mümkündür. Bilimsel alandaki uzlaşmaya ek olarak insan kaynaklı iklim değişikliğinin diğer bir tanımlayıcı niteliği, politik alandaki ayrışmadır. Politik alanda yalnızca iklim değişikliğinin negatif sonuçlarının değil, azaltım politikalarının maliyetlerinin de toplumdaki farklı kesimler tarafindan yüklenileceği ve paylaşılacağı aynı derecede açıktır. İklim değişikliği, iki önemli değer arasında kalan modern dünya için büyük bir zorluk teşkil etmektedir. Bir yanda, insan kaynaklı iklim değişikliğinin yaşanmakta olduğunu ve gerekli tedbirlerin ivedilikle alınması gerektiğini işaret eden bilim bulunmaktadır. Diğer yanda ise, demokratik ilkeleri idealize eden ve varlığı ekonomik refahın sürekli olarak yükselmesine dayalı olan modern politik sistem bulunmaktadir

Anahtar Sözcükler: Küresel Isınma, İklim Değişikliği, Hükümetlerarası İklim Değissikliği Paneli

\section{Theoretical Articles}

\section{GLOBAL WARMING AND CLIMATE CHANGE: FROM SCIENTIFIC CONSENSUS TO POLITICAL DIVISION}

\begin{abstract}
The scientific consensus on climate change among leading climate scientists can be observed in the peerreviewed climate science literature. In addition to the consensus in the science world another defining quality of the anthropogenic climate change is the division in the political sphere. In the political arena, it is equally evident that not only the negative consequences of climate change but also the cost of mitigation policies will be borne and shared by the different parties in the society. Climate change poses a tremendous challenge for modern society, which is caught between two key values. On the one hand, there is the science, which is the last judge of the contemporary world which decides that climate change is occurring, and urgent action is needed. However, on the other hand, there is the current political system that idealizes democratic principles and justifies its existence based on the continuous increase of economic wealth.

Keywords: Global Warming, Climate Change, Intergovernmental Panel on Climate Change

${ }^{1}$ Prof. Dr., İstanbul Üniversitesi, İktisat Fakültesi, İktisat Bölümü, sdogan@istanbul.edu.tr

${ }^{2}$ Doç. Dr., İstanbul Üniversitesi, İktisat Fakültesi, İșletme Bölümü, ebruseng@istanbul.edu.tr

${ }^{3}$ Istanbul Üniversitesi, Sosyal Bilimler Enstitüsü, İktisat Anabilim Dall, mutlutuzer@gmail.com Makale Geliş Tarihi/Received: 07.07.2020, Makale Kabul Tarihi/Accepted: 06.11.2020.
\end{abstract}




\section{GíRiş}

Küresel ısınma ve iklim değişikliğinin bilimsel ve teknik bir problemden küresel barış ve refahı tehdit eden politik bir soruna nasıl evrildiğini inceleyen bu çalışmada, bilimsel ve politik alanda ortaya çıkan temel ayrışma ortaya konulmaya çalışılmıştır. Küresel ısınma ve iklim değişikliğine ilişkin bilimsel teori, beşeri faaliyetlerin doğal karbon döngüsü ve atmosferin 1şınımsal özelliklerini değiştirebilecek bir ölçeğe ulaştığına işaret etmektedir. Bilim, atmosferdeki sera gazı yoğunluğunun iklim sistemine tehlikeli bir beşeri müdahaleyi önleyebilecek düzeyde tutulabilmesinin en temel yolunun, atmosfere bırakılan sera gazı miktarının atmosferden doğal yollarla çekilen sera gazı miktarına eşitlenmesi olduğuna dikkat çekmektedir. İklim değişikliği, büyük ölçüde yeryüzünün enerji dengesi ve karbon döngüsü gibi pozitif bilimsel yasa ve süreçler üzerinden açıklanan bir konu olsa da daha derin bir analiz, sorunun kaynağında hayat ve tüketim standartlarını sürekli olarak yükseltmek amacıyla hareket eden milyarlarca kişinin kararlarının yattı̆̆ını göstermektedir.

İklim değişikliğine yol açan insan kaynaklı sera gazlarının ekonomik faaliyetlerin ayrılmaz bir bileşeni olması, gezegen üzerinde yaşayan herkesi potansiyel olarak küresel bir problemin hem sorumlusu hem de mağduru haline getirmektedir. İklim ve refah arasındaki sıkı bağlantı, olası etkiler ve mücadele politikalarının zorunlu kıldığı kaynak tahsis tercihleri nedeniyle iklim değişikliğine, bilimsel bir problem olmanın ötesinde yadsınması neredeyse imkânsız olan politik bir boyut kazandırmaktadır. İklim değişikliği kaynaklı gelecekte ortaya çıkabilecek olası zararları önlemek ya da azaltmak için toplumun bugünkü tüketiminden ne kadar fedakârlık yapması gerektiği, sera gazı azaltımının hangi hızda olacağı, hangi politikaların daha etkin olacağı ve ortaya çıkacak maliyetlerin taraflar arasında sorumluluk ve kabiliyetleri ölçüsünde nasıl bölüştürüleceği, ulusal ve uluslararası alanda ortaya çıkan politik ayrışmanın cevap bulmaya çalıştığ sorular arasında yer almaktadır. Pozitif bilimin ortaya koyduğu doğal gerçekler ile modern politik sistemin doğal çoğulculuğu arasındaki ikilemin, yüzyılın sonunda ortaya çıkabilecek iklim tablosunu belirleyen temel kuvvetler olmaya devam etmesi muhtemel görünmektedir.

\section{KÜRESEL ISINMA VE İKLIMM DEĞíŞiKLLIĞİ}

Atmosferdeki sera gazı yoğunluğundaki artış ve ortalama yüzey sıcaklıklarındaki yükselme arasındaki ilişki, küresel ısınma ve iklim değişikliği üzerindeki bilimsel tartışmaların temelini teşkil etmektedir. Genel olarak birbirlerinin yerine kullanılsalar da iklim değişikliği biliminde küresel ısınma ve iklim değişikliği farklı süreçleri temsil eden kavramlardır. İlk olarak; küresel ısınma süreci bir gezegen olarak Dünya'nın toplam enerji dengesi üzerinden açıklanan bir kavramdır. Bu noktada küresel ısınma sürecini, enerji ve madde korunumu gibi birincil fiziksel yasalara indirgeyerek açılamak mümkündür. Örneğin; akım ve stok kavramlarını temel alan bir yaklaşım benimsendiğinde sera 
gazlarının atmosferdeki yoğunlukları (ya da sera gazı stoğu), sera gazlarının atmosfere eklenme hızları ile atmosferdeki yıkım ya da çıkış hızları (ya da akımları) arasındaki denge tarafından belirlenmektedir. Bir sera gazının üretim hızı (atmosfere salınım miktarı) eğer atmosferdeki yıkım hızından fazla ise sera gazının atmosferdeki yoğunluğu artmalıdır (Archer, 2010: 159,160). Benzer şekilde sera gazları, yeryüzünün kazanmış olduğu 1sıyı uzaya göndermesini engelleyerek, yeryüzünün ışınımsal dengesinde bir bozulma meydana gelmesine yol açmaktadır. Enerji bütçesinde oluşan dengesizliğin termodinamik yasalar gereği sonucu Dünya'nın ısınması ve ortalama sıcaklığının yükselmesi olmalıdır (IPCC, 2013: 14).

Küresel 1sınmaya karşın iklim değişikliği kavramı, enerji bütçesindeki dengesizlik sebebiyle 1sı enerjisi kazanan yeryüzünde, yağış rejimi ve miktarının değişmesi, deniz seviyesinde yükselme, buzul ve buz tabakalarının erimesi, kuraklık ya da sel gibi uzun dönemli ve daha geniş kapsamlı etkileri işaret etmektedir (Farmer \& Cook, 2013: 8). Hava ve iklimi tanımlayan sıcaklık dışındaki diğer unsurlar da düşünüldüğünde, iklim değişikliği sürecinin iklim sisteminde sıcaklık artışının dışındaki gelişmeleri de içermesi gerekmektedir. Bu sebeple iklim değişikliğinin küresel ısınmayı da kapsadığı söylenebilir. Aralarındaki ilişki açısından bakıldığında, basit bir neden-sonuç ilişkisi kurarak küresel 1sınma sebep, iklim değişikliği ise sonuç olarak görülebilir (Incropera, 2016: 19).

Yaşamın devamı kesintisiz bir enerji akımına muhtaçtır. Enerji, evrende pek çok farklı formda var olur. Enerjinin farklı formları arasındaki dönüşüm ise, varlık ve hayatın devamını sağlamaktadır. Bu dönüşümün izlerini, yıldızların enerji kaynağı nükleer füzyon reaksiyonlarından, bir yağmur damlasının sahip olduğu kinetik enerjiye kadar evrenin her yerinde gözlemlemek mümkündür. Enerji dönüşümlerinin değişmeyen kuralı, enerjinin hiçbir zaman yok olmadı ̆̆ı, yalnızca form değiştirdiğidir. Termodinamiğ̈in birinci yasası olarak tanımlanan bu ilke, enerji korunumu yasası olarak da adlandırılmaktadır. Sicaklık, basit bir şekilde bir cismin enerjisinin ölçümüdür. Enerji formları arasındaki dönüşüm, 1s1 ve işık enerjisi arasında da söz konusudur. Isıtılan her cisim çevresine elektromanyetik enerji şeklinde enerji yaymaktadır. Örneğin; $7000{ }^{\circ} \mathrm{C}$ sıcaklık kısa dalga boylu mor ışık, $3500^{\circ} \mathrm{C}$ sıcaklık daha uzun dalga boyuna sahip kırmızı 1şı üretmektedir. Sıcaklık miktarı arttıkça, daha yüksek frekanslı ve kısa dalga boylu mor-ötesi ışınım, X-ışınları ve gamma ışınları üretilmektedir. Kızılötesi ve radyo dalgaları gibi frekansı daha düşük; ama dalga boyu daha fazla olan elektromanyetik dalgalar, görece daha soğuk cisimler tarafından salınır. Dünya'dan çok daha sıcak olan Güneş’ten gelen ışık enerjisinin daha büyük bölümü kısa dalga boyuna sahipken, Güneş’ten gelen enerjiyle ssınan ve çok daha az sıcak olan Dünya'dan salınan enerjinin büyük bölümü uzun dalga boyuna sahiptir (Archer \& Rahmstorf, 2010: 17,18).

Bir sistemin dışarıya verdiğinden daha çok enerji alması (ya da ışık-elektromanyetik dalga absorbe etmesi) ilke olarak enerji dengesi açısından pozitif bir katkı anlamına gelmekte, bu durumda cisim ısı enerjisi kazanmaktadır. Enerji korunumu açısından bir gezegen 
olarak yeryüzünün enerji dengesini değiştirebilecek iki ana sebep bulunmaktadır: Sisteme giren ve sistemi terk eden enerji miktarının değişmesi. Yeryüzü sistemine Güneş’ten yeryüzüne ulaşan kısa dalga boyuna sahip olan enerji girerken, yeryüzünden yansitılan uzun dalga boyuna sahip enerji yeryüzü sistemini terk etmektedir. Güneş’in enerji çıktısını belirleyen döngüler (Güneş’te bulunan on bir yıllık leke sayıları döngüleri gibi) ve Dünya yörüngesi (Güneş'e uzaklık, eksen eğikliği vb.) ile ilgili parametreler, yeryüzüne ulaşan güneş ışınımı miktarını etkileyen temel faktörlerdir (IPCC, 2007: 96,97).

Saniyede $3,89 \times 10^{26} \mathrm{~J}$ (Joule) enerji üreten Güneş, 3,89 $\times 10^{26} \mathrm{~W}$ (Watt) gücündeki bir motor gibi çalışmakta ve üretmiş olduğu enerjiyi her yöne doğru elektromanyetik enerji şeklinde salmaktadır. Güneş’ten salınan elektromanyetik enerji, uzay boşluğu içinde herhangi bir engelle karşılaşmadan yol alarak Dünya'ya ulaşmaktadır. Dünya, Güneş’ten ortalama 150 milyon km uzaklıkta bulunmaktadır. Dolayısıyla, Dünya atmosferinin üst katmanlarına ulaşan elektromanyetik enerji miktarı, Güneş’i içine alan ve yarıçapı 150 milyon km olan hayali bir kürenin yüzeyine dik olarak ulaşan enerji miktarı kadar olmalıdır. Buna göre, atmosferin üst katmanlarına ulaşan enerji miktarı, yaklaşık olarak 1368,3 W/m² olarak hesaplanmaktadır. Atmosferin üst katmanlarına ulaşan enerji miktarı, Güneş Sabiti olarak ifade edilmektedir. Güneş Sabiti'nin büyüklügüu, öncelikle gezegenin Güneş'e olan uzaklığının bir fonksiyonudur. Örneğin; aynı değer Güneş'e daha yakın olan Merkür için $9147 \mathrm{~W} / \mathrm{m}^{2}$, daha uzak olan Mars için 591,9 W/m² olarak hesaplanabilir. Dünya yaklaşık olarak küre şeklinde olduğu için, dünya yüzeyine ulaşan enerji miktarı için Güneş Sabit'ini küre yüzeyine uygun olacak şekilde hesaplamak gerekmektedir. Daire ve küre yüzey alanlarından hareketle, küre yüzey alanının aynı yarıçaplı daireden 4 kat daha fazla olması sebebiyle, güneş sabitinin miktarı dörtte biri düzeyinde olmalıdır. Buna göre, Dünya atmosferine giren Güneş enerjisi miktarı yaklaşık olarak $342 \mathrm{~W} / \mathrm{m}^{2}$ olmaktadır (Smil, 1999: 3-5).

Yeryüzü sistemini terk eden enerji miktarını belirleyen iki ana değişkenden bahsetmek mümkündür. $\mathrm{Bu}$ değişkenlerden birincisi gezegenin albedosu, ikincisi ise atmosferin 1şınımsal geçirgenliğidir. Albedo, basit bir cismin üzerine düşen ışığı yansıtma oranıdır. Bulutlar, yeryüzündeki buz tabakaları, kar örtüsü ve çöller gibi açık renkli yüzeyler üzerlerine düşen ışığın daha büyük bir kısmını geri yansitırken; karalar, okyanus, orman gibi koyu renkli yüzeyler üzerlerine düşen 1şığı emerek gezegenin ısınmasına yol açmaktadır. Atmosferin üst katmanlarına ulaşan elektromanyetik enerjinin bir bölümü (yaklaşık olarak \%30'u) uzaya geri yansıtılmaktadır. Bulutlar ve atmosfer içinde bulunan aerosol adı verilen küçük katı parçacıklar, yansıtılan Güneş 1şı̆̆ının yaklaşık olarak 2/3'ünden sorumludur. Yansitılan ışığın geri kalan üçte birlik kısmı, Dünya yüzeyinde bulunan kar, buz çöller gibi daha açık renkte olan coğrafi oluşumlar tarafindan gerçekleştirilmektedir. Uzaya geri yansıtılmayan ışık, yeryüzü ve atmosfer tarafindan emilir. Emilen enerji miktarı yaklaşık olarak $235 \mathrm{~W} / \mathrm{m}^{2}$ kadardır. Dünya, termodinamik yasalar gereği dışarıdan enerji gelişinin ve dışarıya enerji çıkışının olduğu açık bir sistemdir. En temel düzeyde ve uzun dönemde yeryüzündeki ortalama sıcaklıklar, bu iki 
enerji akımı arasındaki dengenin sonucunda oluşmaktadır. Buna göre, Dünya enerji dengesinin sağlanabilmesi için metrekare başına yeryüzü ve atmosfer tarafindan emilen $235 \mathrm{~W} / \mathrm{m}^{2}$ miktarındaki enerjinin uzaya geri gönderilmesi gerekmektedir. $235 \mathrm{~W} / \mathrm{m}^{2}$ düzeyinde enerji salınımı için $-19^{\circ} \mathrm{C}$ sıcaklık gerekmektedir. Oysa, Dünya'da ortalama yüzey sıcaklığ $15^{\circ} \mathrm{C}$ dolaylarındadır (Kiehl \& Trenberth, 1997: 205,206).

$\mathrm{Bu}$ sonucun ortaya çıkmasının temel nedeni, yeryüzünün sahip olduğu atmosferdir. Atmosferdeki bazı gazların Güneş’ten gelen kısa dalga boyundaki 1şı̆̆a karşı daha geçirgen; ancak, yeryüzünden yansıyan uzun dalga boyundaki ışınıma karşı daha az geçirgen olması sebebiyle yeryüzü, daha fazla isınmaktadır. Dünya'nın 1sıl dengesini sağlayan söz konusu doğal süreç, atmosferin sera etkisi olarak adlandırılmaktadır. Atmosferin doğal sera etkisine ek olarak enerji, tarım, sanayi ve ulaştırma gibi sektörlerde artan ekonomik faaliyetler, atmosferdeki sera gazı konsantrasyonlarını arttırmakta ve doğal sera etkisini güçlendirmektedir. Bu durum, bir gezegen olarak yeryüzü enerji dengesinde pozitif bir katkının ortaya çıkması sonucunu doğurmaktadır. Hükümetlerarası İklim Değişikliği Paneli'nin (HIDP) yayımlamış olduğu son iklim raporuna göre; fosil yakıt emisyonları ve arazi kullanımındaki değişimler başta olmak üzere beşerî faaliyetlerin tümü göz önünde bulundurulduğunda, 1750-2011 yılları arasında metrekare başına 2,29 Watt'lık bir ısıtma etkisi söz konusudur (IPCC, 2013: 14).

Atmosferde sera etkisine sahip olan gazlar; su buharı, karbondioksit $\left(\mathrm{CO}_{2}\right)$, ozon $\left(\mathrm{O}_{3}\right)$, metan $\left(\mathrm{CH}_{4}\right)$ diazotoksit $\left(\mathrm{N}_{2} \mathrm{O}\right)$, halokarbonlar ve diğer endüstriyel gazlardır. Endüstriyel gazların dışındaki gazlar, doğal olarak atmosferde bulunurlar ve atmosferin yaklaşık olarak \%1'ini oluşturmaktadırlar. Atmosferdeki gazların sırasıyla \%78 ve \%21'ini oluşturan azot ve oksijenin sera gazı etkisi bulunmamaktadır. Buna karşın su buharı atmosferde sera gazı etkisi bakımından diğer bütün sera gazlarından çok daha etkilidir. Bu açıdan su buharı, diğer gaz karışımlarının tümünden yaklaşık olarak 5 kat daha fazla 1sı yutma kapasitesine sahiptir. Ancak, insan aktiviteleri atmosferdeki su buharı miktarının doğrudan artmasına sınırlı derecede katkı yapmaktadır. Buna karşın, insan aktiviteleri dolaylı yollardan atmosferdeki su buharı miktarını etkileyerek küresel ısınmaya yol açmaktadır. İlk olarak; insan kaynaklı sera gazları neticesinde yükselen atmosfer sıcaklıkları atmosferin daha fazla su buharını tutmasına neden olmaktadır. Ayrıca, havadaki su buharının artması sıcaklıkların daha da yükselmesine neden olarak pozitif bir geri besleme mekanizması oluşturmaktadır. İkinci olarak; insan kaynaklı önemli bir sera gazı olan $\mathrm{CH}_{4}$, atmosferde az miktarda su buharı oluşumuyla sonuçlanan kimyasal tepkimelere maruz kalmaktadır. Bu açıdan su buharı, atmosferde sera etkisi bakımından en önemli bileşen olsa da küresel 1sınmaya neden olan insan kaynaklı bir sera gazından ziyade, küresel ısınmanın neticesinde ortaya çıkan bir geri besleme olarak görülebilir. Temel sera gazlarının atmosferdeki konsantrasyonları, doğal sera etkisinin oluşumu için yeterlidir. Doğal sera etkisi, yeryüzünün ortalama sıcaklığının bu etkinin bulunmadığı bir duruma göre $30^{\circ} \mathrm{C}$ kadar daha fazla olmasını sağlamaktadır (Houghton, 2009: 20-23). 
Yeryüzünün değişen enerji dengesi nedeniyle 1sınması, iklim sisteminde sıcaklık artışı başta olmak üzere, yağış rejiminde farklılaşma, deniz seviyesinde yükselme, buzulların erimesi gibi değişimlere neden olmaktadır. İklim sistemindeki değişimler ise, sosyoekonomik sistemin içinde bulunduğu ya da ilişkide olduğu çevre şartlarını değiştirmektedir. Bu durumda, tarımsal üretimde ürün çeşit ve miktarında değişiklik, kıyı bölgelerinde su baskınları, yeryüzü bitki örtüsünde farklılaşma, okyanus ve denizlerdeki asidifikasyon nedeniyle besin zincirinin etkilenmesi gibi etkiler söz konusu olmaktadır. Dikkate alınması gereken diğer bir nokta; sera gazı emisyonları, küresel ısınma, olası etkiler ve sosyo-ekonomik faaliyetler arasındaki döngüsel ilişkidir. Endüstri, tarım, ulaştırma sektörlerindeki neredeyse tüm ekonomik faaliyetler, atmosfere sera gazı bırakılmasına yol açarken; diğer yandan bütün sosyal ve ekonomik yaşam, değişen iklim koşullarından etkilenmektedir (Nordhaus, 2013: 10,11).

\section{KÜRESEL BİR ÇEVRE PROBLEMI}

Atmosferin doğal sera etkisi, atmosferde artan karbondioksit miktarı, buzul çağları ve iklim değişikliği gibi konular, bilim çevrelerinde 19. yüzyıldan beri tartışılıyor olsa da insan kaynaklı iklim değişikliğinin küresel bir çevre ve güvenlik problemi olarak uluslararası politik gündem içinde kendisine yer bulması 1970-1990 yılları arasında gerçekleşmiştir. İkinci Dünya Savaşı sonrasında başlayan ve altmışlı yıllarda doruk noktasına ulaşan Soğuk Savaş kaynaklı nükleer felaket senaryoları, nüfus artışı, sanayileşme ve ekonomik büyüme ile birlikte çevre sorunları giderek daha görünür hale gelmiştir. Petrol krizleri sonucu ortaya çıkan benzin kuyruklarının akıllara düşürdüğü enerji kıtlığı ihtimalleri gibi farklı etkenlerin de bir araya gelmesi, ekonomik refahın özellikle Batı dünyasında zirveye ulaştığı bir dönemde, insan ve çevre ilişkilerinin yeniden sorgulanmasına uygun bir ortamın doğmasına katkı yapmıştır. Çevre tarihçileri, Rachel Carson'ın endüstriyel kirliliğe dikkat çektiği 1962 yılındaki Sessiz Bahar, Paul Erlich'in nüfus artışını yaklaşmakta olan bir felaketin habercisi olarak betimlediği 1968 yılındaki Nüfus Bombast, 1972 yılında Roma Kulübü tarafından yayımlanan ekonomik büyümenin sürdürülebilirliğinin sorgulandığı Büyümenin Sinırlarl ve E. F. Schumacher'in enerji tasarrufuna dayalı küçük ölçekli üretimi savunduğu 1973 yılındaki Küçük Güzeldir isimli kitaplarını, dönemin düşünce iklimini belirleyen eserler arasında saymaktadırlar (Guha, 2000: 75).

Çevre sorunları ile ilgili duyarlıllğın yükseldiği bu dönemde, ekonomik büyümeyi öncelleyen ortodoks ekonomik yaklaşıma alternatif görüşler de ileri sürülmüştür. Her şeyden önce, işletmeler için büyüme, sadece istenilen bir olgu değil, tartışmasız bir başarı ve etkinlik işareti olarak da kabul edilmektedir (Freeman \& Cameron, 1993: 11). Makro düzeyde ise ekonomik büyüme, yoksulluktan, işsizliğe, çevre kirliliğinden, toplumsal barışa kadar karşılaşılan tüm sorunların çaresi olarak kabul edilmektedir (Daly, 2007: 12). Bununla birlikte, ekonomik sistemin büyüme potansiyelinin yeryüzü sistemi tarafindan sınırlandırılmasının gerekliliği, ekolojik ekonomik bakış açısının temel tezlerinden 
birisini oluşturmaktadır (Roegen, 1999: 2; Daly, 1991: 34; Meadows et al., 2004: 53). Benzer şekilde 1970'lerin sonlarında maliyetleri düşürme ve kârı arttırma gibi nedenler, işletmelerde küçülme trendinin başlamasına katkı yapmıştır. Rekor düzeyde ciro elde eden şirketler yalınlaşmaya devam etmişler ve küçülme, Amerikan şirketleri için neredeyse bir yaşam tarzı haline gelmeye başlamıştır (Mishra, Spreitzer \& Mishra, 1998: 83). Dolayısıyla küçülme, şirketleri ve çalışanları etkileyen önemli bir olgu haline gelmiştir.

Çevresel hassasiyetin yükselmeye başladığı bu dönemde küresel ısınma ve iklim değişikliği problemi, farklı coğrafi ölçeklerde ortaya çıkan hava ve su kirliliği, toprak kaybı, nükleer atıklar, ozon tabakasındaki incelme ve asit yağmurları gibi çevre sorunları arasında kamuoyunun ilgisini bekleyen teknik bir konu durumundadır (Howe, 2014: 136,137). Örneğin; iklim değişikliği ile ilgili teorilerin iki yüzyılı bulan geçmişi içinde 1972 yılı gibi göreli olarak geç bir tarihte yayımlanmasına karşın, Büyümenin Sinırları isimli kitapta, iklim değişikliği biliminin en önemli grafikleri arasında yer alan ve atmosferdeki sera gazı yoğunluğundaki yükselmeyi gösteren Keeling Ĕgrisi, enerji kullanımından kaynaklanan bir çevre kirliliği problemi olarak sunulmuştur. İlginç şekilde aşırı enerji tüketimi sonucu ortaya çıkan fazla ısının bir termal kirlilik sorunu olarak açıklandığ 1 kitapta ne küresel ısınma teorisine ne de terimin kendisine yer verilmemiştir (Meadows et al.,1972: 72,73).

Bu tablo karşısında, küresel ısınma ve iklim değişikliğinin politik gündemde üst sıralara yükselmesi ve uluslararası diplomasinin bir parçası haline gelmesi nasıl mümkün olmuştur sorusu öne çıkmıştır. Bu konudaki pek çok açıklama arasında objektif ve bağımsız bilim algısına da en uygun olan anlatıya göre, teorilerini daha çok kanıt ile destekleyen ve modellerindeki belirsizlikleri azaltan bilim adamları, 1970'lerden başlayarak birbiri ardına gelen bir dizi bilimsel rapor ve konferans aracillğıyla kamuoyunu, sorunun gerçekliği ve ciddiyeti konusunda ikna etmeyi başarmışlardır (Allan, 2017: 809; Kellogg, 1987: 117-121; Haas, 2000: 561-563; Bodansky, 2001: 25,26). Yalnız iklim değişikliği değil, asit yağmurları, ozon tabakasındaki incelme, nükleer silahların kontrolü, para ve makroekonomik politikalar gibi diğer uluslararası konularda da bir araya gelmiş uzman grupların çalışmalarını teorik bir çerçeveye oturtmak için uluslararası ilişkiler literatüründe kullanılan en yaygın kavramlardan biri, Peter Haas tarafından geliştirilen epistemik topluluk kavramıdır. Epistemik topluluk, belirli bir konu ya da problem hakkında çözüm için uygulanması gerekli politikaları da kapsayan bilgi ve uzmanlığa sahip, yeterlilikleri kamuoyu tarafindan kabul edilmiş profesyoneller ağı ya da grubudur. Farklı ulus, disiplin ve geçmişlerden gelmelerine rağmen epistemik topluluğun üyeleri; (1) benzer norm ve ilkeleri paylaşırlar, (2) nedensellik konusunda aynı inançlara sahiptirler, (3) bilgiyi değerlendirme ve doğrulamak için aynı ölçütleri kullanırlar ve (4) toplum refahına yapılacak katkıdan hareketle ortak çözüm politikalarını savunurlar (Haas, 1992: 3). 
İnsan kaynaklı iklim değişikliğinin uluslararası kamuoyu gündeminde üst sıralara yükselmesine yol açan olay ve süreçleri, Haas'ın ileri sürdüğü epistemik topluluk kavramı ışığında açıklamak mümkündür. İklim değişikliği literatüründe 1970 ve 1971 yıllarında düzenlenen iki önemli toplantı, sürecin önemli kilometre taşları arasında sayılmaktadır. Bu toplantılardan ilki, Massachusetts Teknoloji Enstitüsü tarafından 1970 yılının Temmuz ayında yapılan ve kırka yakın bilim adamının katıldığı Kritik Çevre Sorunları Çalışması'dır. Çalışma grubunun başkanlığını Massachusetts'teki Williams College'te yönetim profesörü olan Carroll L. Wilson, Wilson'un yardımcılığını ise aynı üniversitede Siyaset Bilimi bölümünden William H. Matthews yapmıştır. Toplantının alt başlığ Insanoğlunun Küresel Çevre Üzerindeki Etkisi'dir. Başlıklardan da anlaşılabileceği gibi çevre sorunları küresel bir yaklaşım içinde ele alınmaktadır. Wilson ve Matthews, toplantı sonrasında basılan raporun önsözünde toplantının amacını belirli küresel problemler konusunda çok disiplinli ve sistemik çalışmalar yaparak bilimsel ve toplumsal farkındalık seviyesini yükseltmek ve bilgiye dayalı politikaların geliştirilmesinde bir model olmak şeklinde ifade etmişlerdir (SCEP, 1970: xi,xii). Toplant1, hava kirliliği, jet uçaklarının neden olduğu sirus bulutları, orman kaybı, ses üstü hızlara çıkabilen uçakların olumsuz etkileri, ozon deliği ve iklim gibi konuları araştıran çalışma gruplarından oluşmuştur. İnsan faaliyetlerinin iklim üzerindeki etkisi tartışılan konular arasında kendisine yer bulmasına karşın; toplantıyı izleyen medya mensuplarının asıl odaklandıkları nokta, ses üstü hızlara çıkabilen uçakların çevresel etkileri olmuştur (Kellogg, 1987: 120).

1971 yılının Haziran ayında İsveç'in Wijk kentinde iklim değişikliği konusuna daha yoğun olarak eğilen ikinci önemli toplantı düzenlenmiştir. Bir önceki toplantının başkanlığını da yapan Wilson'ın bu toplantıdaki amacı, uluslararası bilim topluluğunu da konuya dahil etmektir. İsveç Kraliyet Bilimler Akademisi ve İsveç Kraliyet Akademisi yanında özel şirket ve yardım kuruluşlarının da desteğini alan toplantıya ondört ülkeden otuz bilim insanı katılmıştır. Toplantı sonrasında yayımlanan raporun ismi İnsanoğlunun İklim Üzerindeki Etkisi Çalışması'dır. Söz konusu rapor, yine Massachusetts Teknoloji Enstitüsü tarafından basılmıştır. Çalışma, insanoğlunun iklim üzerindeki etkisi üzerine olsa da toplantıya katılan bilim insanları, bu etkinin tam olarak ne yönde ortaya çıkacağı konusunda tam bir mutabakata varamamışıtır. Bilim adamlarından bazıları karbon salınımlarının neden olabileceği ısıtma etkisi, diğerleri ise endüstri ve tarım kaynaklı aerosollerin soğutma etkisinin baskın olma ihtimali üzerinde durmuştur (Kellogg, 1987: 120-122). Raporun sonuçlarının özetlendiği kısımda, insanoğlunun iklim üzerindeki etkisinin tam olarak ne olduğu konusundaki tespitin daha fazla araştırma yapılmaksızın mümkün olmadığının ifade edilmesi bu fikir ayrılığının bir göstergesi olarak kabul edilebilir (SMIC, 1971: 3).

1979 yılındaki iki büyük bilimsel etkinlik bu sürecin kilit adımları arasında sayılabilir. İlk etkinlik, 1979 yılının Şubat ayında Dünya Meteoroloji Örgütü (WMO-World Meteorological Organization) tarafindan İsviçre'nin Cenevre şehrinde düzenlenen İklim ve İnsanlık Üzerine Uzmanlar Konferansı isimli Dünya İklim Konferansı'dır. ABD Ulusal 
Bilimler Akademisi başkanı olan Robert M. White (1924-2010) toplantının başkanlığını yaparken, kuruluşundan itibaren hazırlamış olduğu değerlendirme raporları ile iklim değişikliği konusundaki uluslararası gündemi belirleyen HiDP'nin, 1988-1997 yılları arasındaki ilk başkanlığını yapacak olan İsveçli meteorolog Bert Bolin de (1925-2007) konuşmacılar arasında yer almaktadır. White, açııı̧ konuşmasında, artık bilim adamlarının iklim konusundaki endişelerinin bilimsel ve teknik konuların ötesine geçerek ekonomik ve sosyal alana kadar uzanması gerektiğini ifade etmiştir. White'a göre, bilim adamlarının görevi, yalnızca bilimin yapması gereken ile sınırlı değildir. Bilim insanları, hükümetlerin bilmesi gerekenleri de tanımlamalıdır (White, 1979: 9). Konferans'ın sonuç bildirgesinde, küresel ısınma ve iklim değişikliği teorisinin gelecek yıllarda da büyük oranda değişmeden kalacak olan ana hatları çizilmiş̧tir: Fosil yakıtların yakılması, ormansızlaştırma ve yüzey kullanımındaki değişimler nedeniyle atmosferdeki karbondioksit miktarı geçen yüzyıldan itibaren $\% 15$ yükselmiştir. Yeryüzü sıcaklığının belirlenmesinde kritik role sahip atmosferde karbondioksit miktarındaki yükselme devam etmesi durumunda alt atmosferdeki isınma sürecektir. Değişimlerin detayları belirsiz olsa da yaşanan süreç, nihayetinde sıcaklık, yağış ve diğer meteorolojik parametrelerin de dağılımını etkileyecektir (WMO, 1979: 714).

İklim konusunda 1979 yılındaki ikinci önemli etklinlik ise, Temmuz ayında ABD Ulusal Bilimler Akademisi tarafından oluşturulan geçici çalışma grubunun yayımlamış olduğu Karbondioksit ve İklim Raporu isimli çalışmadır. Rapor, Jule Charney başkanlığında hazırlanmış olduğu için iklim değişikliği literatüründe Charney Raporu olarak bilinmektedir. Jule Charney (1917-1981), bilgisayarlı ilk sayısal hava tahmin modelinin geliştirilmesini hedefleyen projede, 20. yüzyılın en önemli bilim insanlarından birisi olan John Von Neumann (1903-1957) ile çalışarak projenin başarıya ulaşmasında çok büyük bir rol oynamış dönemin en saygın bilim adamları arasında yer almaktadır. Charney Raporu, sonraki yıllarda iklim değişikliği biliminin genel çerçevesini oluşturacak olan iki nokta konusunda önemli kabul edilebilir. İlk olarak, Robert White'ın tanımladığı gibi rapor, siyaset ve ekonomi dünyasının bilmesi gerekenleri beklendiği gibi niceliksel olarak ifade etmektedir (Allan, 2017: 809). Jule Charney, sorunu oldukça açık bir formüle indirgemiştir: İklim duyarlılığı olarak ifade edilen bu formülasyona göre, eğer atmosferdeki karbondioksit yoğunluğu Sanayi Devrimi öncesi döneme göre iki katına çıkarsa, yeryüzündeki ortalama sıcaklıkların $3{ }^{\circ} C^{\prime}$ ye kadar yükseleceği öngörülmektedir. Yapılan öngörü için verilen $\pm 1,5^{\circ} \mathrm{C}$ yanılma payı ise iklim değişikliği bilimi için sonraki yıllarda alışıldık hale gelen ihtiyatlı yaklaşımı gösteren başka bir detaydır. Charney Raporu'nun iklim değişikliği bilimi açısından öne çıkan diğer bir özelliği ise, ulaşılan sonuçların büyük oranda bilgisayar destekli iklim modellerine dayalı olmasıdır (NAS, 1979: 2).

Seksenli yıllar içinde birbiri ardına gelen bir dizi uluslararası toplantı ve konferansın ardından Dünya Meteoroloji Örgütü, 1988 yılında Kanada'nın Toronto şehrinde 27-30 Haziran günleri arasında Değişen Atmosfer: Küresel Güvenlik Açısından Olası Sonuçları 
isimli bir konferans düzenlemiştir. Farklı ülkelerden gelen temsilciler ve üçyüzün üzerinde bilim adamının katıldığı Toronto Konferansı öncelikle siyaset ve bilim dünyasının buluşturması açısından önemlidir. Küresel ısınma ve iklim değişikliğini, insanoğlu tarafından küresel ölçekte yürütülen arzu edilmeyen geniş sonuçları olabilecek bir deney olarak tanımlayan konferansın sonuç bildirgesine göre; karşı karşıya kalınan tehditten daha kötüsü ancak küresel düzeydeki bir nükleer savaş olabilir. Toronto Konferans1, konunun bilimsel ve teknik alanın ötesine geçerek devletlerin gündeminde küresel refahı tehdit eden bir güvenlik problemi statüsü kazanması açısından kritik adım olarak kabul edilebilmektedir (Allan, 2017: 809-811). Tarihsel süreç içinde değerlendirildiğinde Toronto Konferans1, on yıl kadar önce Cenevre'de Michael White'ın bilimin politikacıların ne bilmesi gerektiği konusundaki sorumluluğuna ilişkin ifadeleri açısından da önemli bir aşamayı temsil etmektedir.

Küresel ısınma ve iklim değişikliği konusunda bilim ve siyasetin yollarının kesiştiği 1988 yılının Haziran ayında, uluslararası toplum başka bir kritik toplantıya daha tanıklık etmiştir. NASA Goddard Uzay Araştırmaları Enstitüsü'nün başkanı olan James Hansen, Toronto Konferansı'nın başlamasından yalnızca dört gün önce 23 Haziran 1988 günü ABD Senatosu Enerji ve Doğal Kaynaklar Komitesi'nde küresel 1sınma ve iklim değişikliği üzerine açılamalarda bulunmuştur. Saygın bir iklim bilimci olarak Hansen'in senatörler karşısında, artan sera gazı ve yükselen sıcaklıklar üzerine yapmış olduğu bilimsel bir sunumu da içeren tanıklığı, küresel ısınma ve iklim değişikliğinin uluslararası alanda küresel bir çevre sorunu statüsü kazanarak geniş kitlelere duyurulmasında önemli bir rol oynamıştır (Revkin, 2018).

1988 yılının son günleri ise, uluslararası düzeyde yaklaşı on yıldır sürdürülen çabaların nihayete erdiği bir gelişme ile sonuçlanmıştır. 6 Aralık 1988'de, Birleşmiş Milletler Genel Kurulu'nun 43/53 numaralı önergesi ve Birleşmiş Milletler Çevre Programı ile Dünya Meteoroloji Örgütü'nün işbirliğiyle Hükümetlerarası İklim Değişikliği Paneli (HIDP), iklim değişikliği konusunda bilimsel değerlendirmeler yapmak üzere uluslararası bir organizasyon olarak kurulmuştur. Üye hükümetleri ve uluslararası kamuoyunu iklim değişikliği biliminin güncel durumu, iklim değişikliğinin potansiyel etkileri, taşıdığı riskler ve iklim değişikliği ile mücadele politikaları konusunda bilgilendirmek, HiDP'nin öncelikli amacı olarak belirlenmiştir (IPCC, 2019).

\section{BIILIMSEL UZLAŞMA}

Küresel ısınma ve iklim değişikliğinin uluslararası refah ve güvenliği tehdit eden küresel bir çevre sorunu etiketinin altı, oldukça geniş sayılabilecek bir bilimsel literatür tarafından doldurulmuştur. Örneğin; uluslararası kamuoyunun ilgisine paralel olarak, iklim değişikliği konusunda yapılan bilimsel çalışmaların sayısı büyük bir hızla artmıştır. 1991 yılında iklim değişikliği ile ilgili yayımlanan bilimsel çalışma sayısı yılda yüz adet iken, 2010 yılına gelindiğinde bu sayı bini aşarak yaklaşık olarak on katına çıkmıştır. Bu artış, 
iklim değişikliği literatürünün her 5 ila 6 yılda iki katına çıktığı anlamına gelmektedir. 1980-2012 yılları arasında Web of Science'ta yayımlanmış makaleler üzerinde yapılan bir araştırmaya göre; toplam bilimsel yayınların iki katına çıkma süresi olan yirmidört yıl ile karşılaştırıldığında iklim değişikliği bilimi literatürünün sıradışı bir hızda genişlediği görülmektedir (Haunschild et al., 2016: 7,8).

İklim değişikliği üzerine olan bu literatür genişlemesini HİDP’nin düzenli aralıklarla hazırlayarak uluslararası kamuoyuna duyurduğu iklim değişikliği raporlarının boyutlarında gözlemlemek de mümkündür. Panel'in 1990 yılında yayımlamış olduğu ilk değerlendirme raporu yaklaşık 1.040 sayfa iken, 2013 yılında yayımlanan son rapor 4.850 sayfadır. Yapılan çalışmalar yalnızca üretilen bilgi miktarındaki arışı değil, aynı zamanda iklim değişikliği biliminin nasıl uluslararası ölçekli ve endüstriyel nitelikte bir girişime dönüştüğünü de gözler önüne sermektedir. 2013 yılında yayımlanan son değerlendirme raporunda yer alan Birinci Çalışma Grubu'na ait Fiziksel Bilim Raporu, 63 ülkedeki 1000 aday arasından seçilen 209'u baş yazar olmak üzere 800'den fazla yazarın katkılarıyla hazırlanmıştır. Raporda 9.200 adet bilimsel referans kullanılmış ve rapor ile ilgili olarak 55 ülkeden 1.089 uzman, 54.677 adet yorum ve değerlendirme yapmıştır (IPCC, 2014: 1).

Bilimin ilke olarak modern yaşamda dünyayı anlama ve açıklama çabaları içinde en önemli araçlardan biri olması, bilimsel çalışmaların sonuçlarını da önemli hale getirmektedir. İdeal koşullarda bilim, toplumsal hayattaki işlevini, pozitif ve normatif boyutları olan problemleri mümkün olduğu ölçüde tarafsız bir perspektiften ele alarak gerçekleştirmeye çalışmaktadır. Bilimsel veri ve kanıtlara dayalı olarak ortaya konulan nesnel gerçekler, bu sayede öznel kabul edilen değer ve kanaatlerden ayrılmaktadır. Bu nitelikler, bilim insanlarına sorunların çözümünde nihai bir hakem rolü kazandırmaktadır. Bu yüzden bilim insanlarının iklim değişikliği ile ilgili ulaştıkları sonuçların, rasyonel kararların dayanabileceği sağlam bir zemin oluşturması beklenmektedir. Bununla birlikte, kamuoyunun gündemindeki her konuda olduğu gibi, iklim değişikliği konusunda da farklı bilimsel görüşlerin bulunması doğaldır. Genellikle olasılıklara referans yapan koşullu bir dille konuşan modern bilim, sınırları daima açık, sonu ve kesinliği olmayan bir girişimdir. Bilim insanları, yapmış oldukları araştırmada kullandıkları yöntem ve veri kaynaklarını diğer bilim insanlarına açmak zorunda oldukları gibi, kendi uzmanlık alanlarının dışında kalan konular söz konusu olduğunda da genellikle diğer bilim insanlarının çalışma ve görüşlerine güvenmek zorundadırlar. Bilim insanları arasında işbölümü ve ortak çalışmayı zorunlu kılan koşullar, bilimi büyük ölçüde sosyal bir faaliyet haline getirmektedir. Disiplinlerarası niteliği dikkate alındığında, küresel ısınma ve iklim değişikliği konusunda da durumun bundan farklı olmasını beklemek doğru değildir (Hulme, 2009: 106).

Bilimsel yaklaşıma özgü, daima olasılıklara referans verilerek yapılan ihtiyatlı açıklamaların aksine, yapılan bilimsel araştırmalar, konunun uzmanları arasında bir fikir birliği olduğuna işaret etmektedir. Örneğin; bilim tarihçisi Naomi Oreskes, iki bine yakın alıntı yapılan 2004 yılındaki çalışmasında, 1993-2003 yılları arasında Uluslararası Bilim 
Endeksi (International Science Index) veri tabanında, anahtar kelimeleri arasında iklim değişikliği bulunan 928 bilimsel makale üzerinde yapmış olduğu araştırmaya dayanarak, hiç bir makalenin insan kaynaklı iklim değişikliği tezini reddetmediğini ileri sürmüştür. Oreskes, incelediği çalışmaları; insan kaynaklı iklim değişikliğinin yaşanmakta olduğuna dair bilimsel uzlaşmaya açıkça destek verenler, iklim değişikliğinin potansiyel etkileri, mücadele politikaları, araştırma yöntemleri, paleoklimatolojik analizler ve insan kaynaklı iklim değişikliği tezini reddedenler olmak üzere altı kategoriye ayırmıştır. Makalelerin \%75'i, ilk üç kategori içinde yer aldıkları için açık ve örtülü olarak iklim değişikliğinin yaşanmakta olduğu tezini onayladıkları kabul edilmiş̧ir. Araştırma yöntemleri ve paleoklimatolojik konularla ilgili geriye kalan \%25'lik bölümün ise, insan kaynaklı iklim değişikliği konusunda açık bir pozisyon almadığı görülmüştür (Oreskes, 2004: 1686).

Aynı veri bankası içinde, 2013 yılında 29.083 yazar tarafından yazılmış 11.944 bilimsel makale üzerinde yapılan diğer bir çalışmada, insan kaynaklı küresel ısınmanın gerçekliği konusunda \%97'nin üzerine çıkan bir uzlaşma olduğu sonucuna ulaşılmıştır (Cook et al., 2013: 3,6). İklim değişikliği konusundaki bilimsel uzlayışı ortaya çıkarmak için yapılan başka bir çalışmada ise, makale veri tabanları yerine akademik kurumlar tarafindan listelenmiş yeryüzü bilim dallarında çalışan 10.257 adet akademisyen arasında anket araştırması tercih edilmiştir. Akademisyenlere internet aracıllğıyla gönderilen ankette iki adet soru sorulmuştur. İlk soru, 1800'lü yıllar öncesi ile karşıllaştırıldığında küresel ortalama sıcaklıkların yükselip yükselmediği; ikinci soru ise insan faaliyetlerinin değişen ortalama sıcaklıklara önemli derecede katkı yapıp yapmadığıdır. Anket gönderilen uzmanlar arasından 3.146 tanesi katılım göstermiştir. Sonuçlara göre; uzmanların \%90'1 ilk soruya sıcaklıkların yükseldiği, \%82'si ise beşeri faaliyetlerin sıcaklıkların yükselmesinde önemli bir faktör olduğunu onaylayan doğrultuda cevap vermiştir. Çalışmanın diğer bir sonucu, küresel ısınma ve iklim değişikliği üzerindeki uzlaşmaya katılma oranının, konu üzerindeki uzmanlığa bağlı olarak yükselmesidir. Çalışma alanını iklim değişikliği olarak belirten ve hakemli dergilerdeki çalışmalarının \%50'den fazlasını iklim değişikliği üzerine yapmış olan uzmanların \%96,2'si küresel ortalama sıcaklıkların yükseldiğini, \%97,4'ü ise insan faaliyetlerinin bu yükselmede rolü olduğunu ifade etmişlerdir (Doran \& Zimmerman, 2009: 22,23).

Konu, kurumsal alana taşındığında, ulusal düzeydeki bilimsel akademi ve organizasyonların da bilim insanlarının çalışmalarını destekler resmi pozisyonlara sahip oldukları görülmektedir. Örneğin; 2001 yılı gibi erken bir tarihte, aralarında Türkiye Bilimler Akademisi (TÜBA)'nin de bulunduğu onyedi ulusal bilim kurumu, insan kaynaklı iklim değişikliği tezini destekleyen ortak bir bildiriye imza atmıştır (AAAS, 2001: 1261). Benzer şekilde, ABD Bilim İlerleme Derneği (The American Assosication for Advancement of Science), 2009 yılında yönetim kurulu ve onsekiz adet bilimsel organizasyon adına insan kaynaklı iklim değişikliğinin yaşanmakta olduğu ve toplum yaşamı için bir tehdit oluşturduğunu ilan eden bir bildiri yayımlamıştır (AAAS, 2009). 
Yapılan bir araştırmaya göre seksen ülkenin ulusal bilim akademileri, iklim değişikliği konusundaki mevcut bilimsel uzlayışı desteklemektedir (Cook et al., 2016: 1).

Beşeri faaliyetler ve iklim değişikliği arasındaki ilişki, HiDP tarafından da teyit edilmiştir. HIDP, doğrudan bilimsel araştırma ve iklim modeli üretmeyen ya da meteorolojik ölçümler yapmayan bir kurumdur. Öncelikle hakemli bilimsel dergilerde yayımlanmış çalışmaları değerlendiren HIDP, kurulduğu 1988 yılından 2019 yılına kadar beşi iklim değerlendirme raporu olmak üzere, sera gazı emisyon senaryolarından yenilenebilir enerji kaynakları ve temiz karbon depolamaya kadar iklim değişikliği ile bağlantılı konular üzerine onlarca özel rapor yayımlamıştır. Panel'in hazırlamış olduğu iklim değerlendirme raporlarında, insan kaynaklı etkiler ve iklim değişikliği arasındaki ilişki konusunda giderek daha kesin ifadeler kullanıldığı görülmektedir. Örneğin; 1990 yılında yayımlanan ilk değerlendirme raporunda, güçlendirilmiş sera gazı etkisinin gözlemler yoluyla açık tespitinin on yıl ya da daha uzun bir süre olası olmadığı belirtilmiştir (IPCC, 1990: xii). HIDP tarafından 1995 yılında yayımlanan ikinci değerlendirme raporunda ise, toplanan kanıtların dengesinin küresel iklim üzerinde farkedilebilir bir insan etkisi olduğunu ima ettiği ifade edilmiştir. HiDP'nin terminolojisine göre, gözlemlenen ısınma eğiliminin doğal nedenler sebebiyle ortaya çıkması olası değildir (IPCC, 1996: 3,5).

Panel, 2001 yılında yayımlamış olduğu üçüncü değerlendirme raporunda, yeni kanıtlar 1şığında bakıldığında ve kalan belirsizlikler hesaba katıldığında, son 50 yılda gözlemlenen ısınmanın büyük bölümünün olası sebebinin sera gazı yoğunluklarındaki yükselme olduğu sonucuna varmıştır (IPCC, 2001: 10) 2007 yılındaki dördüncü raporda ise, bir adım daha ileri gidilerek olası ifadesinin yerine oldukça olası ifadesi tercih edilmiştir. Dördüncü değerlendirme raporuna göre, 20. yüzyılın ortasından itibaren küresel ortalama sıcaklıklarda gözlemlenen artışın büyük bölümünün oldukça olası sebebi, antropojenik sera gazı yoğunluklarında gözlenen yükselmedir (IPCC, 2007: 10). 2013 yılında yayımlanan son değerlendirme raporunda tercih edilen ifade ise, aşırı derecede olasıdır. Panel, 1951-2010 yılları arasındaki küresel ortalama yüzey sıcaklıklarındaki gözlemlenen artışın yarıdan fazlasının aşırı derecede olası sebebinin, sera gazı yoğunluklarındaki antropojenik kaynaklı yükselme ve diğer antropojenik zorlamalar olduğunu belirtmiştir (IPCC, 2013: 17). HiDP'nin bilimsel kanıtların güvenilirliği ve uzmanların görüşlerine dayanarak oluşturduğu terminolojiye göre; aşırı derecede olası ifadesi, \%95'ten fazla bir oranı temsil etmektedir. HIDP'nin aşırı derecede olası ifadesinden daha büyük bir oranda kesinliği temsil etmek için tanımlandığı ifade, \%99 ila \%100 arasındaki olasıllığı gösteren neredeyse kesin ifadesidir.

\section{POLITIIK AYRIŞMA}

Bilim dünyasından gelen uyarılar karşısında uluslararası kamuoyu da küresel hayat ve refahı tehdit ettiği ifade edilen bu problem karşısında tümüyle sessiz kalmamıştır. 1992

yılında iklim değişikliği ile mücadeleye ilişkin hedeflerin belirlenmesi ve bu hedeflerin 
ülkeler arasında ne şekilde paylaşılacağına ilişkin maddeleriyle uluslararası iklim değişikliği müzakerelerinin dayandığı ilk belge olan Birleşmiş Milletler İklim Değişikliği Çerçeve Sözleşmesi (IDÇS, UNFCCC-United Nations Framework Convention of Climate Change) imzalanmıştır. İDÇS, aralarında Türkiye'nin de bulunduğu 197 ülke ve Avrupa Birliği tarafından kabul edilmiştir. Ekleri de dahil edildiğinde yirmialtı sayfa uzunluğunda olan ve yirmialtı ana maddeden oluşan İDÇS'nin 2. maddesine göre; sözleşmenin nihai hedefi, atmosferdeki sera gazı yoğunluklarının iklim sistemine tehlikeli bir beşeri müdahaleyi önleyecek düzeyde dengelenmesidir. Bu nihai hedef, ekosistemlerin doğal olarak iklim değişikliğine uyum sağlayabileceği bir zaman çerçevesinde, gıda üretimini tehdit etmeden ve ekonomik gelişmenin sürdürülebilir bir şekilde devam etmesini mümkün kılacak bir şekilde gerçekleştirilmelidir. İDÇS'de ekonomik gelişme ve iklim sistemi arasında kurulmaya çalışılan ideal dengenin bir gereği olarak, gelişmiş ve gelişmekte olan ülkeler arasında iklim politikaları açısından bir uzlaşma sağlanabilmesi için Sözleşme'nin 3. Maddesinde, iklim değişikliği ile mücadelenin ülkeler tarafından ortak bir şekilde yürütülmesi gerektiği ifade edilmiştir. Bununla birlikte aynı madde içinde, ortak mücadelede ülkelerin yapacağı katkıların, sorumluluk ve kabiliyetleri nispetinde olması gerektiği kabul edilmiştir (UNFCCC, 1992: 4). İDÇS müzakerelerinde gelişmiş ve gelişmekte olan ülkeler arasındaki farkları dikkate alan ve uzlaşmaya varılmasını sağlayan ortak fakat farklılaştırılmış sorumluluklar ilkesi, sonraki yıllarda ülkeler arasında oluşan politik ayrışmanın temel kaynağı haline gelmiştir.

2018 yılı sonuna kadar İDÇS'de belirlenen nihai hedefe ulaşılması için Sözleşme'ye taraf olan ülke lider ve temsilcileri, bilim insanları, medya mensupları, sivil toplum kuruluşları ve çevre koruma örgütlerinin temsilcilerinin de katıldığı yirmidört adet Taraflar Toplantısı düzenlenmiştir. İklim değişikliği ile mücadelede uluslararası sistemin en önemli yapı taşları olan Kyoto Protokolü ve Paris Anlaşması, İDÇS kapsamında müzakere edilerek kabul edilmiştir. Kyoto Protokolü, IDÇS'deki hedeflere uygun olarak Japonya'nın Kyoto şehrinde 11 Aralık 1997 tarihinde imzalanarak 16 Şubat 2005 tarihinde yürürlüğe girmiştir. Protokol'de EK-I ülkeleri olarak nitelendirilen gelişmiş ülkeler, ortalama sera gazı emisyonlarını $\% 5$ oranında azaltma taahhüdünde bulunmuşlardır. 2015 yılında ise, Paris'te yapılan İDÇS'nin 15. Taraflar Toplantısı, iklim değişikliği müzakerelerinde Kyoto Protokolü'nün yerini alacak uluslararası bir anlaşmaya varılmasıyla sonuçlanmıştır. 5 Ekim 2016'da belirlenen en az 55 ülke ve \%55 emisyon sınırının aşılmasıyla Paris Anlaşması 4 Kasım 2016'da yürürlüğe girmiştir. Paris Anlaşması'nda iklim değişikliği tehdidine karşı küresel mücadeleyi güçlendirmek için Kyoto Protokolü'ndeki sera gazı emisyon hedefinden farklı olarak, bu yüzyılda ortalama yüzey sıcaklıklarındaki artışı Sanayi Devrimi öncesi döneme göre $2{ }^{\circ} \mathrm{C}$ 'nin altında tutmak ve 1,5 ${ }^{\circ} \mathrm{C}$ 'lik hedefi gerçekleştirmek için gerekli çabaların gösterilmesi konusunda uzlaşmaya varılmıştır (UNFCCC, 2019).

HIDP'nin kurulmasının ardından geçen otuz yılda, onbinlerce sayfalık bilimsel çalışma, sayısız toplantı, panel, ulusal ve uluslararası düzeydeki farklı alanlara yayılmış girişime 
rağmen, atmosfere bırakılan sera gazı miktarındaki artışın devam ettiği görülmektedir. Uluslararası Enerji Ajansı (UEA, IEA- International Energy Agency)'na göre fosil kaynakların yakılması sonucu ortaya çıkan karbondioksit emisyonları, 1990 yılında 20,5 milyar ton iken 2016 yılında \%57 oranında artarak 32,3 milyar tona ulaşmıştır (IEA, 2018: 25). 1990 yilında 354 ppm (parts per million, milyonda bir parçacık) olan atmosferdeki karbondioksit yoğunluğu ise 2018 yılı sonunda 408 ppm olmuştur (Tans \& Keeling, 2019). Atmosferdeki karbondioksit yoğunluğu için $450 \mathrm{ppm}$ değeri, ortalama yüzey sıcaklıklarındaki değişmenin son onbin y1l içindeki $2{ }^{\circ} C^{\prime}$ lik dalgalanma bandı içinde kalması için kritik bir eşik olarak görülmektedir. HiDP'nin 2018 yılı sonunda yayımladığı ve Paris Anlaşması'nda belirlenen hedefleri değerlendirdiği özel raporuna göre; sanayi öncesi dönem ile karşılaştırıldığında ortalama yüzey sıcaklıklarındaki yükselme şimdiden $1{ }^{\circ} C^{\prime}$ 'ye ulaşmıştır (IPCC, 2018: 6). Dünya Meteoroloji Örgütü, 18 Ocak 2018 tarihinde yapmış olduğu açıklamada 2015, 2016, ve 2017 yıllarının en sıcak yıllar olduğunu ifade etmiştir. Yapılan açıklamaya göre doğrudan aletli sıcaklık ölçümlerinin yapıldığı ondokuzuncu yüzyılın ikinci yarısından sonraki dönem göz önünde bulundurulduğunda, 2016 yılı Sanayi Devrimi öncesine göre $1,2^{\circ} \mathrm{C}$ ile en yüksek sıcaklık artışının hesaplandığı yıl olmuştur. 2015 ve 2017 yıllarında ise aynı döneme göre sıcaklık artışının $1,1^{\circ} \mathrm{C}$ olduğu tespit edilmiştir (WMO, 2018).

Konunun uzmanlarının vermiş olduğu verilere dayanılarak yapılan çok basit bir hesap bile iklim sistemindeki kritik eşiklerin aşılmamasını sağlayacak güvenli karbon bütçesinin giderek daraldığını göstermektedir. 1750-2011 yılları arasında atmosfere salınan 555 milyar ton karbonun, 315 milyar tonu iklim sistemindeki doğal süreçler yoluyla atmosferden çekilmiş, 240 milyar tonu yani yaklaşık olarak \%56'sı atmosferde kalmıştır. Atmosfere salınan insan kaynaklı karbondioksitin kabaca yarısı okyanus, yarısı ise karalar tarafından atmosferden çekilmiştir. Sanayi Devrimi öncesi dönemde, atmosferdeki karbon yoğunluğu 280 ppm'dir. 2011 yllındaki ortalama karbondioksit yoğunluğunun 390 ppm olduğu varsayılırsa, atmosferde kalan 240 milyar ton karbon, atmosferdeki karbondioksit yoğunluğunu referans alınan dönem içinde 110 ppm yükseltmiştir (IPCC, 2013: 486). Bu değerlerden hareket edildiğinde atmosferde kalan her 1 milyar tonluk karbonun atmosferdeki karbondioksit yoğunluğunu yaklaşı olarak $0,5 \mathrm{ppm}$ yükselttiğini söylemek mümkündür. Eğer 1990 yılı baz alınırsa, atmosferdeki karbon yoğunluğu otuz yılda 54 ppm yükselmiştir. 450 ppm sınırına yalnızca 42 ppm kaldığına göre, iklim sistemine tehlikeli bir beşeri müdahaleyi engellemek için kalan sürenin geride bırakılandan daha az olduğu görülmektedir.

Birleşmiş Milletler Gelişme Programı yöneticiliği de yapmış hukuk profesörü James Gustave Speth, ozon tabakasındaki deliğin önlenmesine yönelik olarak referans aldığı ve uluslararası çevresel yönetimin en ideal örneği olarak gördüğü 1987 y1lında imzalanan Montreal Protokolü'nden yola çıkarak, ideal bir dünyada küresel çevre yönetiminin dört önemli aşamadan geçmesi gerektiğini savunmaktadır. Söz konusu aşamalar: (1) İlk olarak, bilim adamları yapmış oldukları araştırmalar ile problemi tespit ederek hükümet dışında 
yer alan çevrelerin güvenilir bilimsel verilere dayalı bir gündem oluşturmalarını sağlamalıdır. (2) Daha çok araştırma ve objektif veriler yardımıyla sorunun gerçekliği konusunda haberdar ve ikna olan uluslararası toplum, geniş politik hedefleri müzakere etmeli ve bu politik hedefleri başarmak için bir çerçeve sözleşme üzerinde anlaşmaya varmalıdır. (3) Ulusal düzeyde yürütülen politik faaliyet ve kampanyalar, Birleşmiş Milletler kurallarına uygun olarak sistemleştirilen uluslararası sözleşmenin ulusal hükümetler tarafından kabul edilerek imzalanmasını sağlamalıdır. (4) Nihayetinde yürürlüğe giren anlaşma ya da protokoller uygulanmalı, gözlemlenmeli ve zaman içindeki başarılarına bağlı olarak revize edilerek güçlendirilmelidir (Howe, 2014: 254).

Küresel ısınma ve iklim değişikliği, teorik düzeyde Speth'in çizmiş olduğu ideal senaryoya uymasına rağmen, sera gazı emisyonlarının azaltımı açısından hedeflenen sonuçlara ulaşılamamıştır. Bununla beraber, bilim insanları arasındaki uzlaşma politik alana taşınamamış; iklim değişikliği ve potansiyel zararları gösteren bilimsel tablo netleştikçe, ilginç bir şekilde gerekli adımların atılmasını sağlayacak olan politik irade zayıflamış; iklim değişikliğine olan toplumsal ilgi azalmıştır. Olası zarar ve riskler konusunda ne söylenirse söylensin, iklim değişikliği konusundaki gerçekler ile yüzleşmek daha da güç hale gelmiş; iklim değişikliği hızlandıkça ülkeler arasındaki ortak aksiyon sorunu da artmıştır. Ortaya çıkan politik ayrışma tablosunun nedenlerini, ülkeler arasındaki farklar üzerinden okumak mümkündür. 1987 yılında Birleşmiş Milletler Çevre ve Gelişme Komisyonu tarafından yayımlanan Ortak Geleceğimiz isimli raporun girişinde olduğu gibi gezegen olarak tek bir Dünya olmasına karşın, dünya bir değildir. Günümüzde yeryüzünde tabiat özellikleri birbirlerinden farklı altı kıtaya yayılmış, birbirlerinden ulusal sınırlar ile ayrılmış ikiyüze yakın ülkede yedi milyardan fazla insan yaşamaktadır (Speth \& Haas, 2006: 26). 


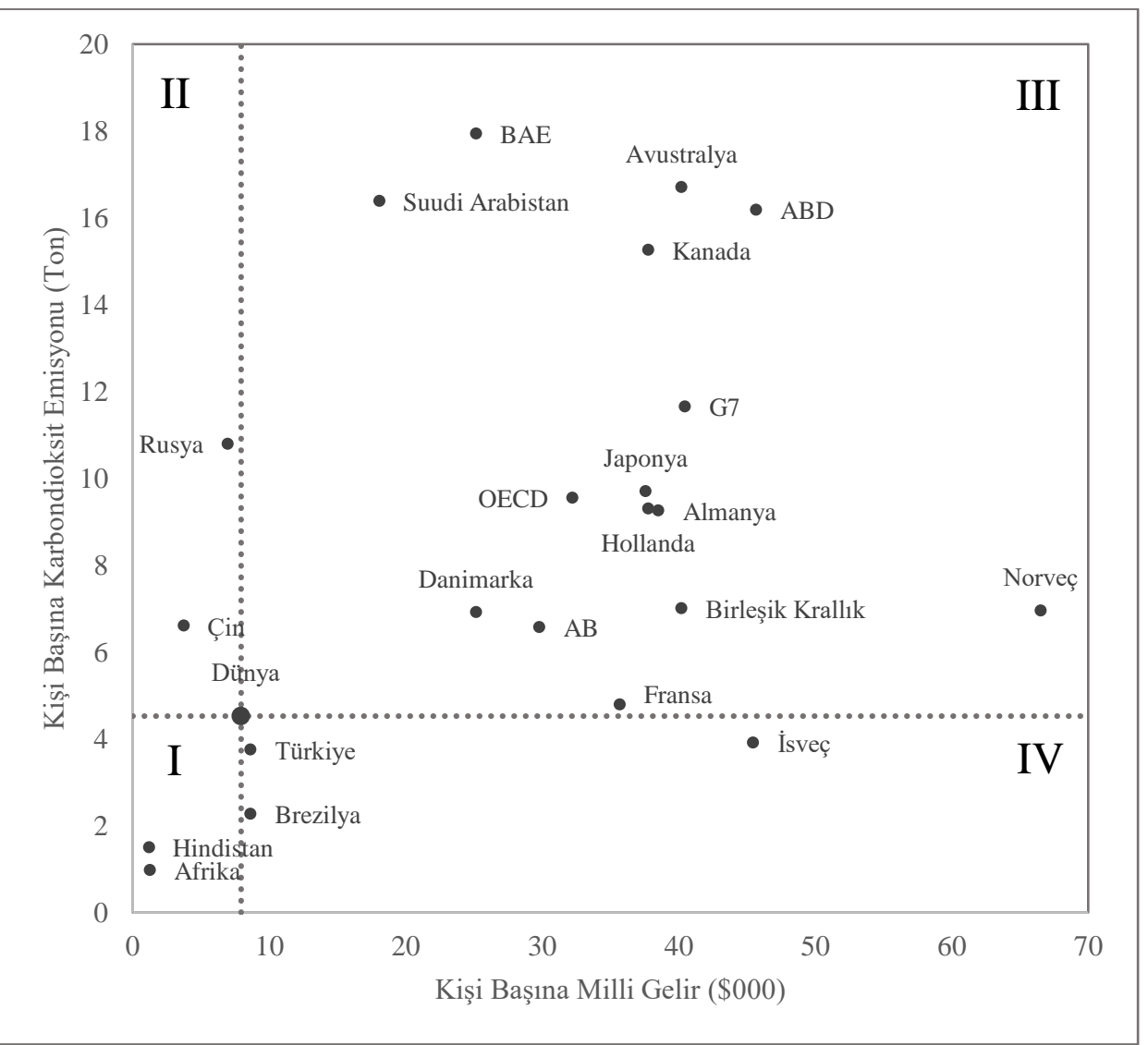

Grafik 1. Kişi Başına Milli Gelir ve Karbondioksit Emisyonları

Kaynak: (IEA, 2015'ten yararlanılarak hazırlanmıştır.)

Grafik 1'de, pek çok ölçüt içinde yalnızca kişi başına milli gelir ve karbondioksit emisyonları açısından bakıldığında bile ülkelerin gerçekte birbirlerinden ne derece farklı oldukları görülmektedir. Grafikte noktalı çizgi ile gösterilen ikinci yatay ve dikey eksenler, kişi başına milli gelir ve karbondioksit emisyon miktarının yaklaşık olarak 8.500 \$ ve 4,5 ton olduğu dünya ortalamalarını temsil etmektedir. Dünya ortalamalarından hareketle grafiği dört bölgeye ayırmak mümkündür. Grafikte her iki ölçüt açısından dünya ortalamasının altında kalan I. bölgede bulunan Afrika ve Hindistan'da iki buçuk milyara yakın insanın yıllık milli gelirleri 1.000 , kişi başına karbondioksit emisyonları ise, ancak 1 ton dolaylarındadır. Enerji sistemi büyük ölçüde kömüre (toplam birincil enerji kullanımının yaklaşık \%62'si) dayalı olan Çin, yüksek büyüme hızı (Çin'in GSYH'sı 
1971 y1lında 150 milyar \$ iken, 2013 yılında 5,1 trilyon \$'a ulaşmıştır) ile kişi başına milli gelir konusunda dünya ortalamasının üzerine çıkmayı başarmış olsa da kalkınma modelinin iklim politikaları açısından sürdürülebilir olmadığı açıktır. Fosil yakıt ihracat gelirlerinin toplam ihracat içindeki payının \%60'ın üzerinde olduğu Rusya'nın fosil yakıt kullanımının düşürülmesi ile sonuçlanacak iklim politikaları konusunda istekli olmasını beklemek, oldukça iyimser bir yaklaşım olarak kabul edilmelidir. Rusya'ya benzer şekilde yalnız politik sistemlerinin sürdürülebilirliği büyük ölçüde fosil yakıt ihracatına dayalı olan Suudi Arabistan ve Birleşik Arap Emirlikleri'nin milli gelir ve kişi başına karbondioksit emisyonları 30.000 \$ ve 20 tona yakındır.

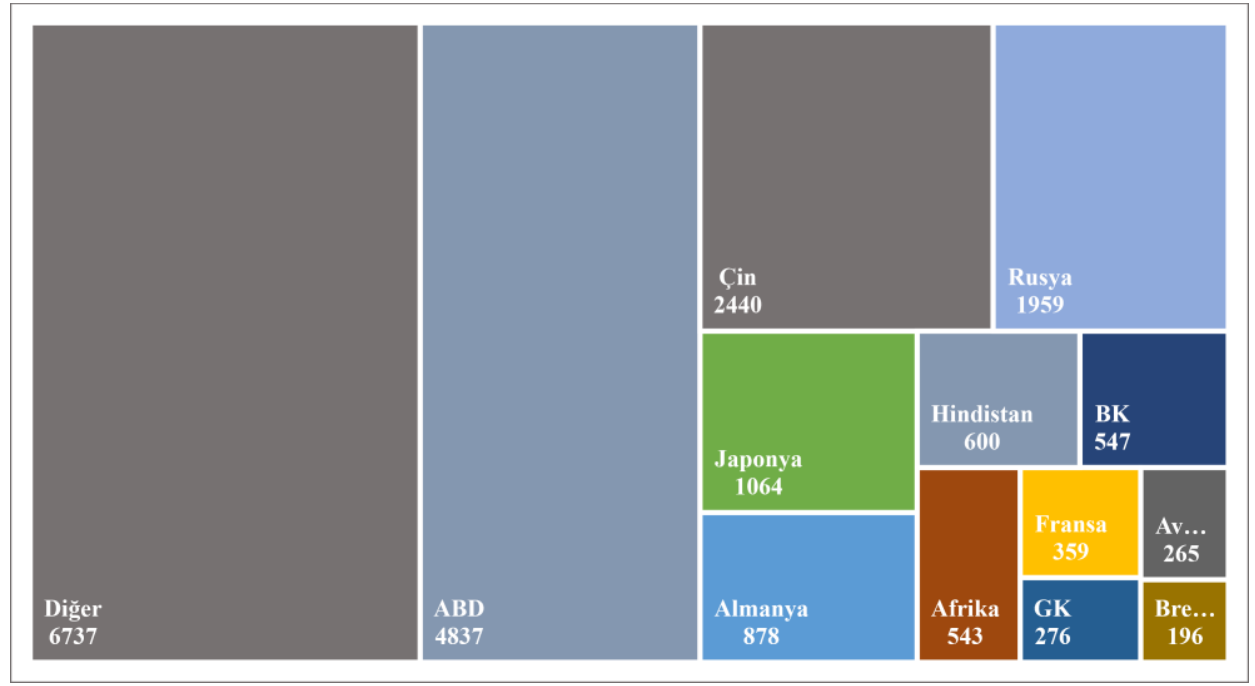

Grafik 2. 1992 Yılı Fosil Yakıt Kaynakı Karbondioksit Emisyonları (Milyon Ton)

Not: Av.: Avustralya, BK: Birleşik Krallık, Bre.: Brezilya, GK: Güney Kore

Kaynak: (IEA, 2015'ten yararlanılarak hazırlanmıştır.)

Kişi başına karbondioksit emisyonları 15 ton dolaylarında olan Kanada ve Avustralya'nın Kyoto Protokolü'nden başlayarak iklim değişikliği konusunda yaşanan tartışmaların odağında olmaları (Avustralya, 1998'de Kyoto Protokolü'nü imzalamış; ancak, 2007'ye kadar onaylamamıştır. Kanada ise, 2011 yılında Protokol'den çekilmiştir) sürpriz olarak görülmemelidir. Dünya'nın en büyük ekonomisi olan ABD’nin, Kyoto Protokolü'nü imzalamasına karşın, onaylamayarak hiçbir zaman Protokol'ün tarafi olmamasını, 2019 yılında ise 2016 yılında imzalamış olduğu Paris Anlaşması'ndan çekilmek üzere başvuru yapmasını, iklim politikaları konusunda ülke içinde ortaya çıkan keskin politik ayrışmanın bir işareti olarak okumak mümkündür. Grafikte ekonomi ve iklim açısından en arzu edilen IV. bölgeye yakın iki Avrupa ülkesinin karbondioksit emisyonları bakımından nötr olarak 
kabul edilebilecek nükleer teknolojiyi enerji sistemleri içinde en yoğun şekilde kullanan İsveç (ülke elektrik üretiminin \%40'ı ve Fransa (elektrik üretiminin \%72'si) olması, diğer bir ilginç noktadır.

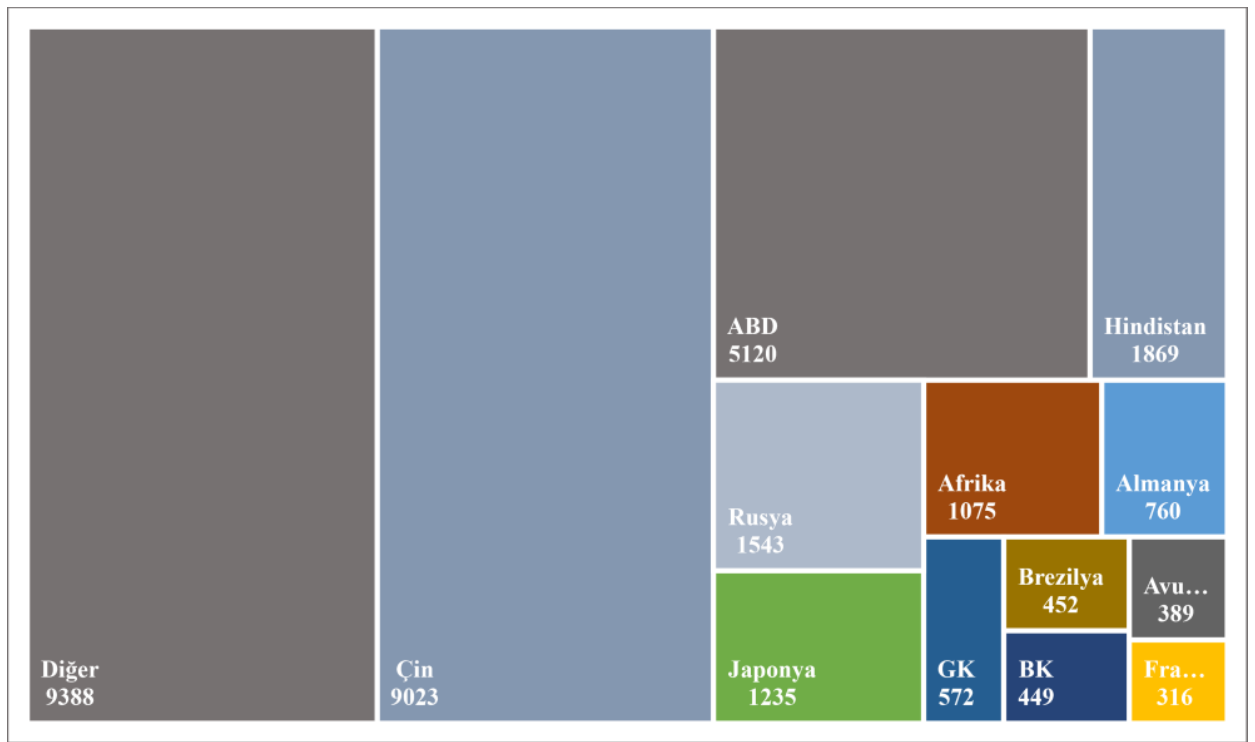

Grafik 3. 2013 Yılı Fosil Yakıt Kaynakı Karbondioksit Emisyonları (Milyon Ton)

Not: Avu.: Avustralya, BK: Birleşik Krallık, Fra.: Fransa, GK: Güney Kore.

Kaynak: (IEA, 2015'ten yararlanılarak hazırlanmıştır.)

Grafik 2 ve Grafik 3, 1992 yılında imzalanan İDÇS'den ve 2015 yılındaki Paris Anlaşması'na kadar geçen sürede, ülkeler arasında dengelerin nasıl değiştiğine ilişkin ipuçları sunmaktadır. Öncelikle, ülkeler arasında zenginlik ve refah açısından ortaya çıkan ayrım, toplam emisyonlar söz konusu olduğunda terse dönmektedir. 1992 yılında karbon emisyonları konusunda birinci sırada olan ABD'nin yerini artık Çin almıştır. İÇ̧S'deki ortak, fakat farklılaştırılmış sorumluluklar ilkesi gereğince Kyoto Protokolü'nde, gelişmekte olan ülkeler arasında sayılarak emisyon azaltım hedefi üstlenmeyen Çin ve Hindistan, artık küresel ısınma ve iklim değişikliği sorununun en kilit ülkeleri haline gelmişlerdir. Avrupa'nın üç büyük ekonomisi olan Almanya, Fransa ve Birleşik Krallık'ın emisyonlarının aynı dönemde mutlak anlamda düşmesi, iklim değişikliği mücadele politikaları konusunda gelişmekte ve gelişmiş ülkeler arasındaki politik ayrışmanın diğer bir belirtisi olarak görülebilir. Sovyetler Birliği’nin dağılmasından sonra geçirmiş olduğu ekonomik dönüşüm, sera gazı azaltım hedefleri konusunda Rusya'nın elini güçlendirmektedir. Küresel ölçekte bir problem olarak tanımlanmasına karşın, ülke 
düzeyinde değerlendirildiğinde; toplam emisyonların yaklaşık \%61'inden yalnızca beş ülkenin (Çin, ABD, Hindistan, Rusya, Japonya, Almanya) sorumlu olması, politik ayrışmanın başrol oyuncuları konusunda dikkati çeken diğer bir ayrıntı olarak ön plana çıkmaktadır.

Anthony Giddens, iklim değişikliği karşısında gerekli adımların atılamamasını Giddens Paradoksu ile açıklamaya çalışmaktadır. Giddens'a göre; iklim değişikliği, günlük hayatın akış1 içinde görünür, somut ve acil olmadığı için toplum, harekete geçmek yerine oturup beklemeyi tercih etmektedir. Ancak, iklim değişikliği günlük hayatın ritmini bozan aşırı hava olayları, tarımsal ürün kayıpları ya da bağlantılı sağlı sorunları gibi zararlar ve doğal felâketler ile görünür ve acil hale geldiğinde, harekete geçip bir şeyler yapmak için çok geç kalınmış olmaktadır. Giddens'e göre, görünmez, soyut, zaman ve coğrafi olarak uzak olarak algılanan iklim değişikliği sorunu; görünür, somut, ve yakın olarak kabul edilen politik ve ekonomik gündem karşısında, bireylerin zihninde ve toplumsal gündem içinde gerçek-altı bir konuma itilmektedir (Giddens, 2011: 2).

Sorunu açıklayan bilimsel teori, genel hatlarıyla bilinmesine ve sera gazı yoğunlukları ile sıcaklıklar arasındaki ilişkinin doğrudan yapılan ölçümlere dayalı olarak ortaya konulmasına karşın, sorunun detaylarının konunun uzmanı olmayanlar tarafından çoğu zaman iyi anlaşılamadığını söylemek mümkündür. İnsan kaynaklı iklim değişikliğini bir yandan modern medeniyetin çöküşüne sebep olabilecek bir felâket; diğer yandan ise, sahte bilime dayalı bir aldatmaca olarak betimleyen iddiaların varlığı, yaşanmakta olan tartışmanın açık bir göstergesi olarak değerlendirilebilir (Attenborough, 2018; Inhofe, 2015). Sayı ve grafiklerle yüklü bilimsel araştırma verilerinin bulunduğu rapor ve makaleler, konuyla doğrudan ilgilenmeyenlerin önüne net olmaktan çok, kafa karışıklığını arttıran bir tablo getirmekte; yaşanmakta olan tartışmayı çözmekten çok, büyütmektedir. Örneğin; yeryüzünün farklı bölgelerinde farklı iklim ve sıcaklık koşulları hâkim olmasına karşın, bütün yeryüzünü temsil eden tek bir sıcaklık değerine nasıl ulaşılmaktadır? Açıklanan değerler yerel iklim ya da hava koşulları açısından nasıl yorumlanmalıdır? Örneğin; küresel ısınma nedeniyle sıcaklık artışı gözleniyorsa neden bazı bölgelerde kış mevsimi geçen yıla göre daha sert geçmiş ve yağış miktarında artış gözlenmiştir? Sicaklık artışları, küresel ısınma ve iklim değişikliğinin bir sonucu olarak ortaya çıkıyorsa neden en sıcak yıl olarak 2016 yılı 2017'nin önünde yer almaktadır? 2017 yılındaki daha düşük sıcaklık verisi, küresel ısınmanın yavaşladığının ya da insan kaynaklı küresel ısınma iddiasının yanlışlığının bir göstergesi olarak mı kabul edilmelidir? Ağustos ayında sabah ve akşam saatlerinde İstanbul'da $10^{\circ} \mathrm{C}$ 'lik bir sıcaklık farkı yaşanırken, Sanayi Devrimi öncesi döneme göre yeryüzünde 2016 yılında $1,2 \quad{ }^{\circ} \mathrm{C}$ 'lik bir sıcaklık artışının hesaplanması, iklim bilimcileri neden endişelendirmektedir?

İklim değişikliği üzerinde araştırma yapan bilim insanlarının üzerinde durduğu tek göstergenin sıcaklık olmadığı, insan kaynaklı yıllık sera gazı salınımlarından atmosferdeki artan sera gazı yoğunluğuna, küresel 1sıtma potansiyelinden karbondioksit eşdeğerine 
$\left(\mathrm{CO}_{2-\text { eş }}\right)$, gezegenin enerji dengesinden pozitif ışınımsal zorlama değerine, karbon döngüsünden denge iklim hassasiyetine, okyanuslardaki termal genişlemeden buz tabakalarındaki yıllık kayıp miktarına kadar çok sayıda kavram ve değişkenin iklim değişikliği sorununu açıklamak için kullanıldığ 1 düşünüldüğünde, yukarıdaki sorulara yenilerini eklemek mümkündür. Yeni sorulara verilebilecek cevapların da beraberinde başka soruları getireceğini tahmin etmek çok da güç değildir. Bu tablo karşısında çözüm, en temel ve basit olana dönerek, sorunun en basit bileşenlerinin gerçekte ne olduğunun anlaşılmasında yatmaktadır. Sorunu oluşturan temel bileşenlerin incelenmesi hedefi, ilk bakışta izlenmesi en makul yol gibi görünse de küresel ısınma ve iklim değişikliğinin disiplinlerarası niteliği basit bir kavramsal çözümleme sonucu ortaya konulabilecek neden-sonuç ilişkilerini ulaşılması zor bir ideal haline getirmektedir. Öncelikle yeryüzü iklim sistemi, farklı bileşenlerin birbirleriyle sürekli evrilen bir etkileşim içinde bulunduğu karmaşık bir sistemdir. Bu karmaşık ve kaotik sistemde doğrusal olmayan değişimlerin varlığı, gelecekte meydana gelebilecek değişimlerin öngörülmesini ve bu değişimlerin sonuçlarının bugünden hesaplanmasını zorlaştırmaktadır (Bolin, 2007: 249).

İklim sistemi ve beşerî sistemler arasındaki karmaşık ve döngüsel ilişkiler, bu zorluğu daha da arttırmaktadır. İklim sistemindeki doğrudan olarak nitelendirilen sıcaklık artışı ve okyanuslardaki asidifikasyon gibi değişimler, sosyo-ekonomik sistemin içinde bulunduğu ya da ilişkide olduğu çevre şartlarını değiştirmektedir. Tarımdan endüstriye, turizmden sağlığa, ulaşımdan yerleşime kadar bütün beşerî faaliyetlerin değiş̧en çevre şartlarından etkilenmesi kaçınılmazdır. Elbette potansiyel etkiler ile sosyo-ekonomik politikalar arasında da bir etkileşim bulunmaktadır. Geniş anlamda sera gazı salınımını belirleyen ekonomik ve sosyal politikalar; dar anlamda ise küresel ısınma ve iklim değişikliği ile mücadele ve uyum politikaları bu etkileşim altında oluşmalı ve bu politikalar sosyoekonomik sistemin sera gazı emisyonlarını etkilemelidir. Başka bir ifadeyle sosyoekonomik strateji ve politikalar iklim sistemindeki değişimlere neden olan sera gazı salınımlarını belirlemekte, iklim sistemindeki değişimlerse sosyo-ekonomik strateji ve politikaların oluşturulmasında önemli bir etken olarak karar süreçlerine dahil olmaktadır (Nordhaus, 2013: 10,11).

Gelecekteki nüfus artışını, ekonomik büyümeyi, bu artış ve büyümenin sera gazı salım miktarını ne boyutta değiştireceği, bu gelişmelerin atmosferdeki sera gazı yoğunluğunda meydana getireceği değişimi, sera gazı yoğunluğunun yeryüzü enerji dengesinde neden olduğu değişiklikleri, yeryüzü enerji dengesinin sıcaklık başta olmak üzere nem, yağış, rüzgâr gibi iklim öğelerinde ortaya çıkartacağı değişimleri küresel ve özellikle bölgesel düzeyde kesin olarak saptamak, imkânsıza yakın bir güçlük arz etmektedir (Bolin, 2007: 198). İklim sisteminde değişime neden olan faktörlerin birbirleriyle olan ilişkileri arasında bir nedensellik ilişkisi kurulabilse bile, büyük çoğunluğu insan kaynaklı olan faktörler dolayısıyla ortaya çıkan değişimin iklim sistemindeki doğal değişim sürecinin ne kadarını temsil ettiği de bir belirsizlik içermektedir. İklim sistemi ile diğer doğal ve beşerî sistemler arasında var olan karmaşık ilişkiler sebebiyle teorik olarak genel hatlarıyla ortaya 
konulabilen nedensellik zinciri iklim sisteminde meydana gelen değişimlerin sosyoekonomik sisteme yansıyan geri bildirimlerinden dolayı çok daha karmaşık hâl almaktadır.

İklim değişikliği üzerine yapılan her çalışmanın, nihayetinde uygulanacak mücadele politikalarına ilişkin bir tartışmaya dönüşmesi, bu noktada doğal kabul edilmelidir. Sorun, bilimsel açıklaması, nedenleri ve sonuçları itibarıyla iklim biliminin kapsamı içinde bulunuyor olsa da yapılan bilimsel çalışmaların ardından sorulabilecek en temel soru ne yapılmalı sorusudur. İklim sisteminde ortaya çıkması muhtemel değişimlerin ekonomik ve sosyal hayata olan etkileri uygulanacak mücadele politikalarından ayrı düşünülemez. İklim şartları başta olmak üzere, her canlı gibi hayatını sürdürmesi için çevresinin kendisine sunmuş olduğu kaynak ve olanaklara ihtiyaç duyan insanoğlu için, iklim değişikliği sorununu ekonomik refah kaygısından ayrı değerlendirmek mümkün değildir. İklim ve beşerî refah arasındaki bu sıkı bağlantı, iklim değişikliğini yalnız ekonomik bir sorun haline getirmekle kalmayarak, olası etki ve mücadele politikalarının zorunlu kıldığ 1 kaynak tahsis tercihleriyle birleşerek, soruna yadsınması neredeyse olanaksız olan politik bir boyut da kazandırmaktadır. İklim-ekonomi-politika üçgeninde, sorunun bilimsel açıdan daha iyi anlaşılmasının mücadele politikalarının belirlenmesi ve uygulanmasındaki işlevi, bilimsel gerçeklere dayalı politika modeline uygun bir yaklaşımdır (Hulme, 2009: 103). Bilim tarafından ortaya konulan, sosyal ve politik açıdan nesnel ve nötr olan gerçeklerin, uygulanması gereken mücadele politikaları konusunda karar vericileri ikna edici, hatta zorlayıcı rolü, ulusal ve uluslararası düzeyde oluşturulmaya çalışılan iklim değişikliği mücadele sisteminin temelini teşkil eden önemli bir ideal olarak görülmüştür (Howe, 2014: 9).

Bilimin zorlayıcı işlevinin rasyonel politikaların geliştirilmesinde oynadığı rol, önemli bir faktör olarak kabul edilse de bu işlevin karar vericiler üzerinde farklı yönlerden etkili olabileceği gözden kaçırılmamalıdır. İklim değişikliği, ilk bakışta enerji ve maddenin korunumu gibi temel fiziksel yasalar aracılığıyla açıklansa da daha dikkatli bir analiz, sorunun kaynağında, hayat ve tüketim standartlarını sürekli olarak yükseltmek amacıyla hareket eden milyarlarca kişinin kararlarının yattığını göstermektedir. Bu noktada iklim değişikliği, tanımlanması kolay olmayan ve çözümü zor olan bir problemdir. İklim değişikliği, kökeni bilimsel ve teknik bir sürece dayalı olsa da nihayetinde sosyal ve politik boyutu ağır basan bir sorundur. Salt teknik ve bilimsel problemlerden farklı olarak, sosyal ve politik sorunlar, kamu politikasının bir bileşeni olarak görülmelidir. Toplumdaki farklı değer, gelenek ve çıkarlar dikkate alındığında, bu tür sorunların nihai çözümünden çok, kabul edilebilir düzeyde kontrol ve yönetiminin daha gerçekçi bir hedef olduğu benimsenmelidir (Incropera, 2016: 14). Bu noktada, iklim biliminin probleme ilişkin ortaya koyduğu gerçekler ile mücadele politikalarının maliyetlerine ilişkin ekonomik ve politik gerçekler arasında, geleneksel bir karşıtlığın yattığını söylemek mümkündür. 
Küresel ısınma ve iklim değişikliği süreci, içinde sayısız detayların bulunduğu, bütününün görülmesi için kendisinden uzaklaşılması gereken dev bir tabloya benzemektedir. Tabloya ancak yakından bakıldığında fark edilebilen detaylar, tablonun tümünü görmek amacıyla uzaklaşıldığında ise gözden kaybolmaktadır. İzleyenlerin gözünde şeffaf ve net bir resimden çok, her şeyin her şeyi etkilediği bir kaos görüntüsüne daha yakın olan bu karmaşık tablo karşısında verilen tepki ise, genellikle kararlılık ve hareket yerine; kararsızlık ve ayrışma olmaktadır. Ortaya çıkan ayrışma ve kararsızlık, sorunun ve yol açabileceği olası zararların anlaşılması amacıyla yapılan on binlerce sayfalık bilimsel çalışma ve mücadele politikaları üzerine iddialı söylemlere rağmen, azalacağ yerde artmaktadır. İnsan kaynaklı iklim değişikliğini; bir yandan felâket, diğer yandan ise, bir aldatmaca olarak betimleyen çok farklı iddiaların varlığını, bu kaotik tablo ile bağlantılı şekilde okumak mümkündür (Attenborough, 2018; Inhofe, 2015).

Bu karmaşık tablo karşısında, küresel ısınma ve iklim değişikliğinin hâlâ bilimsel açıdan büyük oranda sonuca bağlanmamış, üzerinde belirsizliklerin sürüp gittiği bilimsel bir teori olarak algılanmaya devam ediyor olduğu sonucuna varmak mümkündür. En basit tanımıyla teori ya da kuram, gözlemlenen olayları açıklayan ve bir dereceye kadar doğrulanmış sistematik bilgilerin toplamıdır. Bir tarafında doğrulanma, diğer tarafında yanlışlanma olasılığı bulunan bu tanım 1şığında değerlendirildiğinde, teori kavramı akıllara bir uçta ciddi bilimsel çalışmalar yoluyla üretilmiş objektif bilgileri, diğer uçta ise bazı şeylerin olma ihtimaline ilişkin kanıtsız sübjektif spekülasyonları ya da kurguları çağrıştırmaktadır (TDK, 1983; Webster's New World, 2007). Teori kelimesi, bu anlam yelpazesinin spekülasyon ya da kurgu ucuna doğru çekiştirildiğinde, yürütülen mantık oldukça basittir: Küresel ısınma ve iklim değişikliği iddiası bir teoridir. Teori olduğu için kesin değildir. Kesin olmayan bir teori üzerine inşa edilmesi sebebiyle iklim değişikliği hâlâ çözülmeyi bekleyen belirsizliklerin olduğu tartışmalı bir konudur. Rasyonel karar teorisine göre; bir konudaki bilgi kesin değilse en iyi seçenek mevcut durumu koruyarak alınacak kararların neden olabileceği maliyetlerden kaçınmaktır. Başka bir ifadeyle, ortada denemeye değer iyi bir seçenek yoksa en iyi şey, hiçbir şeyin yapılmamasıdır (Oreskes \& Conway, 2010: 409).

\section{BİLIMIN İKÍLEMI}

İklim değişikliği karşısında belirlenen sera gazı azaltımı hedeflerine ulaşılamamasını açıklamak için çok sayıda ekonomik ve politik düşünce ileri sürülebilir. Politik olarak büyük ölçüde kamuoyu görüşlerine bağlı olarak biçimlenen politik ortam ve kamuoyu ilgisi arasındaki ilişki, ilginç bir geri bildirim döngüsüne sahiptir. Kamuoyunun belirli bir soruna karşı ilgisindeki azalma, sorun ile ilgili politik kararlılı̆̆ zayıflatırken; pek çok konuda devletin düzenleyici rolüne ihtiyaç duyan kamuoyu, azalan politik kararsızlığın ürettiği belirsizlik karşısında, mevcut durumu sürdürmeyi tercih etmektedir. Ekonomik rekabet içinde diğerlerinin ne yapacağ 1 konusundaki şüphe ve güvensizlik karşısında girişimde bulunmak yerine, durup beklemenin daha rasyonel göründüğü savunulabilir 
(Helm, 2015: 16). İnsan kaynaklı iklim değişikliğini, ekonomideki ortak ve özel mallar ayrımı ile dışsallık kavramından hareketle bir piyasa başarısızlığı sorunu olarak tanımlamak da mümkündür. Sera gazı emisyonlarına neden olan faaliyetlerde bulunanlar, diğer insanlara ve gelecek nesillere iklim değişikliğinin neden olabileceği maliyetleri yüklerken; piyasa mekanizması ya da diğer yöntemler aracılı̆̆ıyla söz konusu faaliyetlerinin sonuçlarına katlanmamaktadırlar (Stern, 2007: 27). Bu analiz temel alındığında, herkesin kullanma hakkına sahip olduğu; ancak, kimsenin sahibi olmadığı ortak bir kaynağın korunmasından çok, özel amaçlara hizmet edecek şekilde sonuna kadar tüketilmesi, bireysel faydasını maksimize etmeye çalışan ekonomik bireyler açısından en rasyonel hareket tarzını oluşturmaktadır (Hardin, 1968: 1244). Sorunu, piyasa başarısızlığının ötesine taşıyarak modern ekonomik sistemin yapısına bağlayan başka bir görüş̧e göre; fosil yakıtlara dayalı ve büyüme odaklı mevcut kapitalist ekonomik sistem ve devlet müdahalesine karşı serbest piyasa savunucularının direnci, sera gazı emisyonlarının azaltılması konusunda yaşanan aksiyonsuzluğun temel nedenidir (Klein, 2014:18).

Giddens Paradoksu ile açıklanmaya çalışılan tablonun altında, trajik bir şekilde küresel 1sınma ve iklim değişikliği konusunda pozitif bilime her şeyin önünde öncelik veren yaklaşımın yattığını iddia etmek de mümkündür. İklim biliminde modern iklim kavramı, doğrudan deneyimlenemeyen matematiksel bir kurgu, küresel ısınma ise anlaşılması kolay olmayan fiziksel bir teoridir. İklim değişikliği, genellikle küresel düzeyde ifade edilen atmosferdeki karbon yoğunluğu, küresel ısınma potansiyeli, ışınımsal zorlama, iklim hassasiyeti, ortalama sıcaklık artışları, deniz seviyesindeki yükselme, okyanuslardaki asidifikasyon ya da buz tabakalarındaki erime oranı gibi anlaşılması, günlük hayatın akışı içinde belirli bir bağlama yerleştirilmesi çok da kolay olmayan bir takım teknik terim ve değişkenler aracılığıyla tanımlanarak açıklanmaktadır. Örneğin; yirminci yüzyılın ikinci yarısında atmosferdeki karbondioksit yoğunluğundaki artış Keeling Ĕgrisi ile somut olarak görselleştirilebilse bile, kokusuz ve renksiz bir gaz olan karbondioksiti atmosferde görmek mümkün değildir. Fosil yakıtların yakılması sonucu açığa çıkan karbondioksitin \%40'ının atmosfere dağılarak karışmasını duyu organları aracılığıyla algılamak da karbondioksitin uzun dalga boyundaki enerjiyi emerek ışımasına dokunmak da mümkün değildir (Howe, 2014: 29-31).

Sıcaklığın insan vücudundaki soğuk kış günlerindeki rahatlatıcı, yaz aylarındaki bunaltıcı etkisi açıklanmaya gerek olmayan deneyimler iken, iklim değişikliği biliminde sürekli olarak tekrarlanan yeryüzündeki ortalama yüzey sıcaklığındaki yükselme, ilk işitildiğinde kafaları karıştıran matematiksel bir hesaplamadır. Ortalama yüzey sıcaklığı, yeryüzü iklimini küresel ölçekte işleyen fiziksel bir sistem olarak tasavvur eden ve bu sistemin durumunu dijital ortamlarda toplulaştııılmış küresel veriler ile ifadeye etmeye çalışan iklim değişikliği biliminin, küreselleştirme ihtiyaç ve eğiliminin bir yansımasıdır. Yukarıdan aşağıya doğru işleyen bu küreselleştirme eğilimini, Kyoto Protokol'ündeki $\% 5$ 'lik sera gazı salınımı ve Paris Anlaşması'ndaki $2{ }^{\circ} \mathrm{C}$ 'lik sıcaklık artışı hedeflerinde de 
gözlemlemek mümkündür (Hulme, 2010: 560). Kutuplarda eriyen buz tabakaları, yaşam alanları giderek daralan kutup ayıları ya da yok olma tehlikesi ile karşı karşıya kalan mercan kayalıkları ise, sorunun medya organlarındaki küresel düzeydeki görsel sembolleri haline getirilmeye çalışılmıştır (Leiserowitz, 2006: 54). Ancak, bu sembol ve etkiler, sorunun kaynağını oluşturan milyonlarca insanın yaşamında doğrudan gözlenebilir değildir. Küresel ısınma ve iklim değişikliğinin toplum hayatı için neden olduğu meydan okumanın kavranılması, çevredeki dünya ile kurulan anlık ilişkinin ötesine geçen küresel süreçlerin anlaşılmasını gerektirmektedir (Howe, 2014: 29).

Bu karmaşı tablo içinde iklim değişikliği konusundaki belirsizlikleri azaltan veri ve bilginin üretiminde başarılı olunmasına rağmen, ulaşılan sonuçların kamuoyuna iletilmesinde ve konuyla ilgili toplumsal ve politik taleplerin karşılanmasında başarısız olunmaktadır. Bu bilimsel ikilemin çözümü, iklim değişikliği bilimindeki istatistiksel ve genel kavramların özel ve yerel koşullar açısından anlamlı sonuçlara dönüştürülmesinde yatmaktadır. Bir bölgedeki günlük hava koşulları, çoğu zaman yıllık ortalama yüzey sıcaklıklarındaki yıllık ya da on yıllık değişimden daha görünür, acil ve somuttur. Ancak, fiziksel bir temel üzerine inşa edilmiş, küresel bir bakış açısına sahip ve büyük ölçüde bilgisayar modelleri aracılığıyla işleyen iklim değişikliği bilimi düşünüldüğünde, bu problemin çözülmesi çok da kolay görünmemektedir. Sorun, bir yandan yeryüzü ikliminde beşeri algının ötesinde ölçek ve karmaşıklığa sahip olan olay ve süreçlerin doğasından; diğer yandan ise, daha detaylı sonuçlar elde edebilmek için küresel düzeyde geçerli olan denklemleri kullanan ve yukarıdan aşağıya doğru işleyen modern bilimsel yöntemden kaynaklanmaktadır (Gramelsberger \& Feichter, 2011: 9,10).

En basit şekilde tanımlandığında iklim, belirli bir yer ve zamandaki ortalama atmosferik koşulları olarak tanımlanan havanın yıllardan yüzyıllara kadar uzayan zaman içindeki tarihidir. İklim hakkında temel olarak iki yolla bilgi edinilebilir. İlk yol, iklimin geçmişine ilişkin kayıtların toplanmasıdır. Çok düzenli ve kapsamlı olmayan aletli meteorolojik ölçümler 17. yüzyıla kadar gitmektedir. 19. yüzyılın ikinci yarısından itibaren yüzeyden yapılan sistematik ve düzenli gözlemlerin kapsamı, hava balonları yardımıyla yapılan üst atmosfer gözlemleri ve gemiler aracılığıyla toplanan okyanus verilerinin eklenmesi ile genişlemiştir. 20. yüzyıl ise, radar ve uydu gözlemleri gibi yeryüzünü saran elektronik gözlem ağının kurulmasına tanıklık etmiştir. Bütün bu gözlemler, tüm yeryüzünü kapsayan küresel bilginin üretilmesini mümkün kılmaktadır. Aletli ölçümlerin ötesine gidildiğinde ise, paleoiklim verileri yeryüzünün milyonlarca yıllık derin geçmişinden dolaylı yöntemler kullanılarak toplanmak zorundadır. İklim sistemini anlamının ikinci yolu ise, onu fiziksel bir sistem olarak tasavvur ederek üzerinde çalışılabilir bir modelinin üretilmesidir. Teorik olarak sistemin çalışması açısından zorunlu olan temel bileşenler ve aralarındaki etkileşimler yeterince anlaşılırsa sistemin gerçekte nasıl çalıştığı ve gelecekte nasıl değişebileceği öngörülebilir. Ancak, farklı uzay ve zaman ölçeklerinde işleyen atmosfer, okyanuslar, kriyosfer, karalar gibi birbirinin içine geçmiş çok sayıda alt sistemden oluşan yeryüzü iklimi üzerinde laboratuvar ortamında deneyler yapılması 
mümkün değildir. Bu yüzden iklim değişikliği konusunda üretilen bilginin büyük bölümü, bilgisayar modellerine dayanmaktadır. Meteoroloji ve iklim biliminde bir yandan yer istasyonları, gemiler, balonlar ve uydular vasıtasıyla tüm yeryüzünü izleyerek küresel veri oluşturulmaya çalışılırken; diğer yandan, yeryüzünün farklı bölgelerinden farklı zamanlarda farklı kişiler tarafından toplanmış heterojen veriler küreselleştirilerek tutarlı bilgiler üretilmeye çalışılmaktadır (Edwards, 2010: xiv,xv).

Ancak, gözlem ağı vasıtasıyla üretilen bilgi, büyük ölçüde küresel ölçektedir. Paleoiklim arşivlerinden elde edilen veriler yeryüzünün derin jeolojik geçmişine doğru uzanmaktadır. Bilgisayar modelleri ise gerçek dünyanın matematiksel birer sembolü durumundadır. Bu durum, iklim biliminde üretilen bilginin günlük ve gerçek hayattaki anlamını arttırmak yerine azaltmaktadır. Meteoroloji ve iklim değişikliği bilimindeki istatistiksel, dijital ve jeolojik kaynaklı veri ve kavramların bireysel ve yerel bilgiye dönüştürülmesi, küresel bakışın yerel koşullar ile ilişkilendirilebilmesini gerekli kılmaktadır. Bu noktada, toplumun geniş bir kesiminin ya da karar alıcıların bilimsel iklim kavramını öğrenme ve anlama gerekliliği ileri sürülebilir. Buna karşın, iklim değişikliği konusunda somut ve etkin adımların atılmasında niahi rolü küresel sıcaklık istatistiklerinden çok, iklim değişikliğinin yerel düzeydeki etkileri ve bireysel ihtiyaçlar oynayacaktır (Gramelsberger \& Feichter, 2011: 9,10).

\section{SONUÇ}

Çevre üzerindeki pek çok tartışma konusu, bilimsel düşünce ile günlük hayata hâkim düşünce biçimi arasında pozitif ve normatif ifadelere kaynaklık eden farklılıklar ile ilgilidir. Sorunların çözümü yolunda tartışma, uzlaşma ve gerektiğinde ödün verme, toplumsal alanda ideal kabul edilir. Bilimsel düşünce ise, sorunların çözümünü daha katı ve sıkı standartların karşılanması ile gerçekleştirmeye ve pozitif alanda kalmaya çalışır. Gözlem, deney ve mantık yolu ile desteklenmemiş ya da yanlışlanmış bir düşüncenin, uzlaşma ve ödün yoluyla kabul edilmesi mümkün değildir. Bilimsel açıdan genel kanaatlerden ziyade gözlem, deney ve ölçme yoluyla elde edilmiş niceliksel verilere olan uyum, yani gerçekler önemlidir.

Toplumsal uzlaşma idealini bilimsel alana taşımaya çalışmak, çoğunlukla bilimde geçerli olan düşünce biçimini ve bilimin işleyişini doğru bir şekilde anlamamaktan ve uygulamamaktan kaynaklanmaktadır. Gerçekler ve istekler arasında yaşanan bu gerilim, küresel ısınma ve iklim değişikliği sorununda da ön plana çıkmakadır. Mücadele yöntemlerinin yol açtığı ekonomik ve siyasi maliyetler ile iklim sistemini oluşturan fiziksel ve biyolojik süreçler arasında bir sınır bulunmaktadır. Ekonomik ve siyasi maliyetlerin yüksekliği konusunda karar alıcılar ve politika yapıcılar arasında bir uzlaşma bulunabilir. Siyasi alanda sağlanan uzlaşma, kamuoyunun bu konudaki kanaat, değer ve beklentilerine uygun da olabilir. Bu duruma karşın, atmosferdeki sera gazı yoğunlaşması, ortalama yüzey sıcaklıkları, okyanusların asidifikasyonu, buzulların erimesi gibi iklim 
sistemine ait değişkenler, siyasi ve toplumsal alanda var olan uzlaşmaya karşı bir tablo ortaya koyuyorsa, küresel iklim değişikliğinin var olmadığı yönündeki bir toplumsal uzlaşma, bu sorunu ortadan kaldırmaz. Bilginin elde edilme amacı, yapısı, ulaşılması, değerlendirilmesi ve kontrolüne dair günlük yaşam ve bilim arasında ortaya çıkan bu uzlaştırılması kolay olmayan farklar, insan kaynaklı küresel ısınma ve iklim değişikliği konusundaki tartışmaların da alt yapısını oluşturmaktadır.

Sonuç itibarıyla, iklim değişikliği konusunda ortaya çıkan bilimsel tablo, sorunun var olup olmadığı konusundaki tartışmaların büyük ölçüde kapanması gerektiğine işaret etmektedir. Bilimsel alandaki tartı̧̧ma ve belirsizliklerin çoğunun, iklim değişikliğinin olası etkilerinin fiziksel iklim sisteminin diğer bileşenleri ve beşeri sistemler açısından ne derece önemli olduğunun tespit edilmesi ile ilgili olduğu görülmektedir. İhtiyaç duyulan mücadele ve uyum politikalarının maliyetlerinin farklı taraflar arasında nasıl paylaşılacağı sorusu ise, iklim değişikliği problemine bilimsel olmaktan çok politik bir nitelik kazandırmaktadır. Bu tablo, modern toplumun kendisini tanımlayan iki önemli değerinin arasında kaldığını göstermektedir. Bir yanda, insan kaynaklı iklim değişikliğinin yaşanmakta olduğunu ve gerekli tedbirlerin ivedilikle alınması gerektiğini işaret eden bilim; diğer yanda ise, sorunun ciddiyeti konusunda kamuoyunun ikna edilmesini gerekli kılan modern politik sistem bulunmaktadır. 
Seyhun DOĞAN, Ebru DOĞAN, Mutlu TÜZER

\section{KAYNAKÇA}

Allan, B. B. (2017). Second only to nuclear war: Science and the making of exitential threat in global climate governance. International Studies Quarterly, 17, 809-820.

American Assocaiton for the Advancement of Science (AAAS) (2001). The science of climate change. Science, 292(5520), 1261.

AAAS (2009). AAAS reaffirms statements on climate change and integrity. https://www.aaas.org/news/aaas-reaffirms-statements-climate-change-and-integrity.

Archer, D. (2010). The global carbon cycle. Princeton University Press.

Archer, D., \& Rahmstorf, S. (2010). The climate crisis: An introductory guide to climate change. Cambridge University Press.

Attenborough, D. (2018, December 3). David Attenborough: The collapse of the civiliztion on the horizon. The Guardian.

Bodansky, D. (2001). The history of the global climate change regime. In U. Luterbacher, \& D. F. Sprinz (Eds.), International relations and global climate change (pp. 23-40). The MIT Press.

Bolin, B. (2007). A history of the science and policits of climate change: The role of the intergovernmental panel on climate change. Cambridge University Press.

Cook, J., Nucitelli, D., Green, S. A., Richardson, M., Winkler, B., Painting, R., Way, R., Jabobs, P. \& Skuce, A. (2013). Quantifying the consensus on anthropogenic global warming in the scientific literature. Environmental Research Letters, 8, 1-7.

Cook, J., Oreskes, N., Doran, P.T., Anderegg, W. R. L., Verheggen, B, Maibach, E. W., Carlton, J. S., Lewandowsky, S., Skuce, A. G., Green, S. A., Nucitelli, D., Jacobs, P., Richardson, M., Winkler, B., Painting, R., \& Rice, K. (2016). Consensus on consensus: A synthesis of consensus estimates on human-caused global warming. Environmental Research Letters, 11, 1-7.

Daly, H. E. (1991). Steady-state economics (2nd ed.). Island Press.

Daly, H. E. (2007). Ecological economics and sustainable development selected essays of Herman Daly. Edward Elgar.

Doran, P. T., \& Zimmerman, M.K. (2009). Examining the scientific consensus on climate change. EOS Trans American Geophysical Union, 90(3), 22-23. 
Edwards, P. N. (2010). A vast macchine: Computer models climate data and the politics of global warming. The MIT Press.

Farmer, T. G., \& Cook, J. (2013). Climate change science: A modern synthesis: Volume 1-The physical climate. Springer.

Freeman, S. J., \& Cameron, K.S. (1993). Organizational downsizing: A convergence and reorientation framework. Organization Science, 4(1), 10-29.

Giddens, A. (2011). The politics of climate change (2nd ed.). Polity Press.

Gramelsberger, G., \& Feichter, J. (2011). Modelling the climate system: An overview. In G. Gramelsberger, \& J. Feichter (Eds.), Climate change and policy (pp. 9-89). SpringerVerlag Berlin Heidelberg.

Guha, R. (2000). Environmentalism: A global history. Longman.

Haas, P. M. (1992). Introduction: Epistemic communities and international policy coordination. International Organization, 46(1), 1-35.

Haas, P. M. (2000). International institutions and social learning in the management of global environmental risks. Policy Studies Journal, 28(3), 558-575.

Hardin, G. (1968). Tragedy of the commons. Science, 162, 1243-1248.

Haunschild, R., Bornmann, L., \& Marx, W. (2016). Climate change research in view of bibliometrics. PLoS One, 11(7), 1-19.

Helm, D. (2015). The carbon crunch. Yale University Press.

Houghton, J. T. (2009). Global warming: The complete briefing ( $4^{\text {th }}$ ed.). Cambridge University Press.

Howe, J. P. (2014). Behind the curve: Science and politics of global warming. University of Washington Press.

Hulme, M. (2009). Why we disagree about climate change: Understanding controversy inaction and opportunity. Cambridge University Press.

Hulme, M. (2010). Problems with making and governing global kinds of knowledge. Global Environmental Change, 20(4), 558-564.

Incropera, F. P. (2016). Climate change: A wicked problem compexity and uncertainty at the intersection of science, economics, Politics, and Human Behaviour. Cambridge University Press. 
Inhofe, J. (2015, February 2015). Republican Senate environment chief uses snowball as prop in climate rant. The Guardian.

International Energy Agency (IEA) (2015). $\mathrm{CO}_{2}$ emissions from fuel combustion: Highlights. OECD/IEA.

IEA (2018). $\mathrm{CO}_{2}$ emissions from fuel combustion: Highlights. OECD/IEA.

Intergovernmental Panel on Climate Change (IPCC) (1990). Climate change: The IPCC scientific assessment. Cambridge University Press.

IPCC (1996). Climate change 1995: The sciende of cimate change. Cambridge University Press.

IPCC (2001). Climate change 2001: The scientific basis. Cambridge University Press.

IPCC (2007). Climate change 2007: The physical science basis. Cambridge University Press.

IPCC (2013). Climate change 2013: The physical science basis. Cambridge University Press.

IPCC (2014).Working group I fact sheet. https://www.ipcc.ch/site/assets /uploads/2018/03/WG1AR5_FactSheet.pdf.

IPCC (2018). Global warming of 1.5 ${ }^{\circ} \mathrm{C}$. https://www.ipcc.ch/ site/assets/uploads/sites/2/2018/07/SR15_SPM_version_stand_alone_LR.pdf.

IPCC (2019). IPCC about. https://www.ipcc.ch/about/.

Kellogg, W. W. (1987). Mankind's impact on climate: The evolution of awareness. Climatic Change, 10, 113-136.

Kiehl, J.T., \& Trenberth, K. E. (1997). Earth's annual global mean energy budget. Bulletin of American Meteorological Society, 78(2), 197-208.

Klein, N. (2014). This changes everything. Simon\&Schuster.

Leiserowitz, A. (2006) Climate change risk perception and policy preferences: The role of affect imagery and values. Climatic Change, 77, 45-72.

Meadows, D. H., Meadows, D. L., Randers, J., \& Behrens III, W. W. (1972). The limits to growth: A report for the club of Rome's project on the predicament of mankind. Universe Books. 
Meadows, D., Randers, J., \& Meadows, D. (2004). Limits to growth: The 30-year update. Chelsea Green Publishing Company.

Mishra, K. E., Spreitzer, G. M., \& Mishra, A. K. (1998), Preserving employee morale during downsizing. Sloan Management Review, 39(2), 83-95.

National Academy of Sciences (NAS) (1979, March). Report on an ad hoc study group on carbon dioxide and climate. https://www.nap.edu/download/12181\#.

Nordhaus, W. (2013). The climate casino: Risk uncertainty and economics for a warming world. Yale University Press.

Oreskes, N. (2004). The scientific consensus on climate change. Science, 306,1686.

Oreskes, N, \& Conway, E. M. (2010). Merchants of doubt: How a handful of scientists obscured the truth on issues from tobacco smoke to global warming. Bloomsbury.

Revkin, A. (2018, March 2). Climate change first became news 30 years ago. Why haven't we fixed it?. https://www.nationalgeographic.com/magazine/2018/07/embark-essayclimate-change-pollution-revkin/.

Roegen, N. G. (1999). The entropy law and the economic process. Harvard University Press.

Smil, V. (1999). Energies: An illustrated guide to the biosphere and civilization. The MIT Press.

Speth, J. G., \& Haas, P. M. (2006). Global environmental governance. Island Press.

Stern, N. (2007). The economics of climate change: The stern review. Cambridge University Press.

Study of Critical Environmental Problems (SCEP) (1970). Man's impact on the global environment. The MIT Press.

Study of Man's Impact on Climate (SMIC) (1971). Inadvertent climate modification. The MIT Press.

Tans, P., \& Keeling, R. (2019). Trends in atmospheric carbon dioxide. https://www.esrl.noaa.gov/gmd/ccgg/trends/data.html.

Türk Dil Kurumu (TDK) (1983). Türkçe sözlük (7. Baskı). Türk Tarih Kurumu Basımevi. 
United Nations Framework Convention on Climate Change (UNFCCC) (1992). United nations framework convention on climate change. https://unfccc.int/resource/docs/convkp/conveng.pdf, 03 Mart 2019.

UNFCCC (2019). UNFCCC ehandbook. https://unfccc.int/resource/bigpicture/dbook. https://unfccc.int/resource/bigpicture/.

Webster's New World (2007). Webster's new world college dictionary (4th ed.). Wiley Publishing Inc.

White, R. M. (1979). Climate at the millennium: Keynote speech to the world climate conference. https://library.wmo.int/pmb_ged/wmo_537_en.pdf.

World Meteorological Organization (WMO) (1979). Proceedings of the world climate conference: A conference of experts on climate and mankind. https://library.wmo.int/pmb_ged/wmo_537_en.pdf.

WMO (2018), WMO confirms 2017 among the three warmest years on record. https://public.wmo.int/en/media/press-release/wmo-confirms-2017-among-three warmest-years-record. 